\title{
ENTREVISTA COM JADER JANER MOREIRA LOPES
}

\author{
Espaço desacostumado: A Geografia das Crianças e a Geografia na Educação \\ Infantil
}

Jader Janer Moreira Lopes, mineiro de Juiz de Fora, possui graduação em Geografia pela Universidade Federal de Juiz de Fora (1989), mestrado em Educação pela Universidade Federal de Juiz de Fora (1998), doutorado em Educação pela Universidade Federal Fluminense (2003) e pós-doutorado pelo Internationaler Promotionsstudiengang Erziehungswissenchaft/Psychologie- INEDD, da Universität Siegen, Alemanha. Pesquisador da FAPERJ, CNPq e CAPES, coordena o Grupo de Pesquisa e Estudos em Geografia da Infância- GRUPEGI (CNPq/UFF/UFJF) cujo foco principal é produzir conhecimentos relativos às relações que as crianças possuem com os espaços, contribuindo com os recentes (e raros) trabalhos que explicitam diálogos entre a ciência geográfica e o campo de estudos da infância.

As pesquisas do grupo partem do pressuposto que a criança é um ser históricocultural, afirmativa comumente popularizada nos discursos contemporâneos, contudo agrega também ao debate a condição geográfica da infância. Disso desdobram-se alguns argumentos fundamentais, entre os quais se podem destacar três: o primeiro é que o espaço é uma dimensão significativa nos estudos que buscam colocar as crianças como sujeitos protagonistas nas sociedades em que vivem; o segundo é que o processo de humanização das crianças, o seu "ser e estar" no mundo porta também uma grandeza geográfica; e o terceiro refere-se a forma como nós, individual ou coletivamente, concebemos o espaço (e por extensão suas expressões tais como território, lugar, paisagem, região), constituem liames que interferem nas novas formas de ver, compreender, agir com as crianças e na produção de suas infâncias.

Utilizando como referências os estudos histórico-culturais (sobretudo, de Lev Semionovitch Vigotski ${ }^{1}$ e colaboradores) as pesquisas buscam compreender as vivências das crianças com os espaços, inseridos em seus meios e contextos.

Atualmente, Jader Janer Moreira Lopes é professor dos Programas de Pós-graduação em Educação da Faculdade de Educação da Universidade Federal Fluminense (UFF) e da Universidade Federal de Juiz de Fora (UFJF), onde orienta mestrado e doutorado.

A narrativa a seguir refere-se a entrevista realizada por João do Prado Ferraz de Carvalho e Jorge Luiz Barcellos da Silva, professores, respectivamente responsáveis pelos fundamentos teóricos e práticos do Ensino de História e Geografia, do Departamento de Educação da UNIFESP, no contexto dos "Seminários Viajantes", uma das ações do Programa de melhoria da qualidade das licenciaturas - Prodocência - Capes edital 028/2010 que tem como perspectiva agregar elementos que contribuam para a ampliação dos diálogos entre os campos da Geografia e História na formação de professores para a educação infantil e anos iniciais do ensino fundamental e consolidação

1Estaremos usando a grafia do nome Vigotski com "i” e não com Y, por estar em acordo com as recentes traduções apresentadas por Prestes. Ver seu livro: PRESTES, Zoia. Quando não é quase a mesma coisa: Análise de traduções de Lev Semionovitch Vigotski no Brasil. Campinas: Autores Associados, 2012. Olh@res, Guarulhos, v. 2, n. 2, p. 301-334. Dezembro, 2014. 
do Programa de Residência Pedagógica (PRP) do Curso de Pedagogia da UNIFESP. Entendemos que o diálogo com profissionais de outras instituições formadoras e a partilha de experiências exitosas é de grande valia no que tange o desenvolvimento de estudos de aprofundamento relativos à metodologia de formação teórico/prática assim como aqueles relacionados aos processos de ensino e aprendizagens das crianças

A entrevista foi realizada nas dependências da UFJF na manhã de outono do dia 27 de junho de 2013. Na ocasião nos reunimos em uma sala do Programa de Pós Graduação de Educação da UFJF acompanhados de orientandos do Prof. Jader Janer, estavam presentes também o Prof. Cassiano Caon Amorin (PPGE/UFJF), o professor Bruno Muniz (Colégio de Aplicação João XXIII) numa verdadeira roda de conversa iniciamos o diálogo ao qual se incorporou posteriormente a Profa. Zoia Prestes (PPGE/UFF), incrementando a tertúlia. Foram mais de duas horas e meia marcadas por interlocuções muito ricas. Nas páginas que se seguem a narrativa vai evidenciar um geógrafo professor de afinada sensibilidade, preocupado com os estudos de fundamentação teórica aliada as práticas: Jader nos falou com animação sobre seus estudos, trabalho e ações relacionadas às geografias das infâncias.

Olh@res, Guarulhos, v. 2, n. 2, p. 301-334. Dezembro, 2014. 


\begin{abstract}
Vamos iniciar nosso diálogo solicitando que você se apresente ao leitor, narrando alguns pontos de tua trajetória escolar e acadêmica que tem resultado num recorte de preocupações de pesquisa e formação docente bastante singular, aproximando a História e Geografia da área Educação Infantil
\end{abstract}

É uma excelente forma de começar uma conversa, uma entrevista. É necessário situar nossas trajetórias, nossas biografias para as pessoas entenderem como a gente se constrói nas histórias e geografias do mundo vivido e no meu caso, como acabei chegando à Educação Infantil. Fiz a minha graduação em Geografia aqui na Universidade Federal de Juiz de Fora. Isso foi no final dos anos 1980, me formei especificamente em 1990. Naquela época estava sendo amplamente divulgado os estudos de Jean Piaget no Brasil, sobretudo na área da Educação. Ocorreu a reformulação dos programas curriculares para o ensino da antiga $1^{\mathrm{a}}$ à $4^{\mathrm{a}}$ série do ensino fundamental, praticamente em todas as áreas.

$$
\text { Naquele momento, a }
$$

preocupação era como os estudos de Piaget e demais membros do grupo de Genebra, poderiam nos ajudar a pensar e reformular o trabalho com o currículo escolar, compreender a cognição das crianças, seus processos de ensinoaprendizagem, pelo menos era isso que chegava muito fortemente até nós. $\mathrm{O}$ Colégio de Aplicação João XXIII ${ }^{2}$

2 O Colégio de Aplicação João XXIII é uma instituição ligada a Universidade Federal de Juiz de Fora e sempre apresentou estreitas relações de pesquisa como essa, atuando na formação de novos professores. É um campo de estágio das licenciaturas oferecidas pela universidade. Olh@res, Guarulhos, v. 2, n. 2, p. 301-334 sempre teve uma ligação muito forte com a universidade. Era uma grande área de campo de estágio. Inclusive era o único lugar possível, a gente não tinha abertura para fazer estágio em outro local. Às vezes, para você ir para outra escola, tinha que negociar com o professor responsável pela prática de ensino que liberava apenas uma parte em outras instituições. Os professores de Geografia do João XXIII também atuavam muito diretamente com os professores das práticas de ensino que havia aqui na Faculdade de Educação da UFJF. Iniciou-se um movimento pelo grupo da História junto com outras áreas, inclusive a Geografia, que foi pensar o programa do Colégio de Aplicação João XXIII. Como eu era aluno da universidade, eu comecei a participar desse movimento, primeiro como voluntário, depois como bolsista de monitoria. Eu tinha outros focos de interesse dentro da Geografia naquele momento, minha turma foi a primeira de bacharelado da universidade e estávamos muito seduzidos com a possibilidade que esse novo título traria para nós, mas a participação nesses trabalhos, na organização dessa proposta curricular, tendo por base os estudos do Piaget, acabou me instigando a caminhar para o campo da Educação e mais ainda, a do fazer Geografia com crianças pequenas. Começava ai minha inserção e interesse pela área de Ensino e também pela infância.

Foi formulado no colégio um documento, que existe até hoje, coordenado por diversos professores, entre eles a Professora Valéria Trevizani Burla de Aguiar e Maria Eduarda Garcia Cardoso. É um documento clássico,

Maiores informações no endereço:
http://www.ufjf.br/joaoxxiii/

A


explicitando o que todo mundo conhece atualmente, o que está popularizado em diversos textos e livros didáticos: a lógica de que o ensino de Geografia deveria partir de uma "realidade mais próxima" das crianças para a "realidades mais distantes". O currículo foi reformulado seguindo esse princípio: começava-se o primeiro ano estudando o "eu" das crianças, seus nomes, suas identidades, seus gostos, desejos...depois partíamos para compreender a turma, a sala, a escola, o bairro da escola, o bairro dos meninos e meninas e, mais adiante, o município, até chegarmos no estado. $\mathrm{O}$ programa ia até o estado naquela época, fechávamos o ciclo dos primeiros anos da Educação Básica com o estudo do Estado de Minas Gerais. A proposta era passar por todos os níveis, por todas as dimensões dos espaços ocupados pelas pessoas, pelas crianças. Era a compilação dos desdobramentos dos postulados de Piaget, associados a outro livro que também se tornara clássico nos cursos de Geografia: "A Geografia - isso serve em primeiro lugar para fazer a guerra", de Yves Lacoste ${ }^{3}$. O recado para nós ira claro: transitar entre os diversos níveis escalares e reconhecer a descentração espacial da cognição humana, nos levaria a um currículo perfeito para as crianças. Veja que não estou dizendo que essa era a defesa desses autores, mas sim como interpretávamos os discursos. $\mathrm{E}$ foi o que fizemos.

O Colégio de Aplicação João XXIII sempre foi uma referência muito forte aqui na cidade. $O$ que se fazia nessa escola impactava muito a rede municipal e também a rede privada. A

3 A Geografia - isso serve, em primeiro lugar, para fazer a guerra, de Yves Lacoste (editora Papirus, 1988, tradução de Maria Cecília França)

Olh@res, Guarulhos, v. 2, n. 2, p. 301-334. Dezembro, 2014. construção do currículo acabou se espelhando para todo o município de Juiz de Fora e claro, o colégio não estava sozinho, ecos de outros locais, encontros, cursos, evidenciavam um movimento que ocorria em todo Brasil e também no ocidente. Eu estava me formando quando esse documento ficou pronto. Logo depois fiz um concurso para a rede pública. O município estava baseado na reforma do Colégio de Aplicação João XXIII, reorganizando os currículos de todas as suas escolas. Nesse contexto foram criados grupos de várias áreas e o da Geografia era um deles, composto inicialmente pelo professor Wenceslau Machado de Oliveira Júnior, colega de turma de graduação, (atualmente FE/Unicamp), Ancila Maria Bezerra Muniz (professora da rede pública e privada de Juiz de Fora) e mais tarde por mim e com intensa colaboração do professor Vicente Paulo dos Santos Pires (atualmente ICH/UFJF). Atuávamos com a rede de professores de Geografia do município e outros interessados, todos convidados a pensar uma nova organização curricular para a Geografia presente na rede municipal.

A gente trabalhava junto com o pessoal da História, porque a ideia era fazer, dentro da lógica defendida pela Professora Tomoko Iyda Paganelli (exprofessora de Prática de Ensino de Geografia da UFF) em relação às Ciências Sociais, um currículo não separado de Geografia e de História. Nosso objetivo era, então, o de construir um currículo só das Ciências Humanas para toda a rede municipal. $E$ isso foi feito! Estudávamos os textos da professora Tomoko. Ela própria veio a Juiz de Fora algumas vezes nos assessorar. Seus livros circulavam como 
bases para nossas reflexões. Com a mudança de prefeitura, a partir das eleições municipais, o grupo foi desfeito. No entanto os desdobramentos foram muito interessantes, porque a rede privada se apropriou desse material e começou a utilizá-lo como referência. Nesse movimento fomos chamados para poder dar assessoria e trabalhar em outros locais. Dessa maneira cada vez mais fui me inserindo no debate das séries iniciais.

Sua trajetória até o momento nos instiga uma questão, a do currículo na Educação Infantil e a inserção de História e Geografia não de uma forma disciplinar. Como se daria essa inserção nas Ciências Sociais? Principalmente na Educação Infantil, que é um espaço completamente aberto, algo a ser produzido.

Quando comecei a trabalhar na rede privada aqui na cidade, teve início também um maior envolvimento no pensar a Educação Infantil. No grupo da Prefeitura não havia espaço para isso, existia outra comissão que era responsável. A Educação Infantil era um campo muito específico, e nós que vínhamos das diversas áreas de conhecimentos, tínhamos poucas inserções nesse espaço, não nos cabia pensar um currículo para crianças tão pequenas, pelo menos no tocante às contribuições das áreas nesse processo.

Entre as escolas que trabalhei aqui em Juiz de Fora, uma delas teve significativo destaque em minha formação: o colégio Satélite. Tratava-se uma cooperativa fundada por um grupo de pais de um banco público brasileiro, o Banco do Brasil, que buscavam um projeto educativo diferenciado para seus filhos, mais crítico e reflexivo, com bases em teorias contemporâneas que circulavam no período, a perspectiva era pensar a possibilidade de se criar uma escola modelo. A expectativa era agregar professores e demais interessados, num grande colegiado, numa grande cooperativa. Para isso foram convidados professores das várias áreas que tinham alguma inserção nos debates que lhes interessavam. Eu fui para trabalhar com a Geografia da Educação Infantil até o $3^{\circ}$ ano do Ensino Médio, não somente como professor de sala de aula, mas também contribuindo com a formação dos professores das séries iniciais, inclusive a Educação Infantil. Isso acabou me jogando cada vez mais dentro desse trabalho. E continuamos estudando muito, no colégio, dedicávamos horas semanais de leitura e debate compartilhado. Líamos Paulo Freire, Madalena Freire e muitos outros. A concepção de um projeto de educação sério, comprometido e, sobretudo, que envolvesse toda a comunidade educativa no processo, buscando o crescimento mútuo nos animava. Além disso, tínhamos uma certeza, não era possível fazer educação sem conhecer muito profundamente como se desenvolveria a cognição humana. As leituras das obras de Piaget continuavam, agora ampliadas por muitos outros autores que já abordavam as propostas dele para a Educação. Lembro-me que três livros me tocaram muito nesse momento: "A Paixão de conhecer o mundo" 4 de Madalena Freire, onde as narrativas do cotidiano com suas crianças me ensinaram $\mathrm{o}$ profundo respeito $\mathrm{e}$ compromisso com o outro, a importância e necessidade do registro como forma de

4 FREIRE, Madalena. A paixão de conhecer o mundo. Rio de Janeiro: Paz na Terra. 1983

Olh@res, Guarulhos, v. 2, n. 2, p. 301-334. Dezembro, 2014. 
tecer nossas histórias individuais $\mathrm{e}$ coletivas, o compromisso ético que ela tanto defendia, os saberes como promoção do humano, o educar como movimento dialógico...essenciais; o livro "A representação do espaço na criança", também ajudou a entender os processos da cognição espacial das crianças, compreender o desenvolvimento das relações topológicas, projetivas $\mathrm{e}$ euclidianas, mas teve uma outra obra de Piaget que me deixou maravilhado: "A representação do mundo na criança", , as pesquisas que ele descreve nessas páginas me levaram a reconhecer que as crianças pensam de forma diferenciada dos adultos, possuem lógicas próprias. Reconheço todos os questionamentos e críticas construídas, hoje, em relação ao pensamento desse autor, mas não posso negar o impacto que esse material teve em minha própria forma de conceber as crianças, de ler as infâncias. Mais tarde um outro livro seu: O juízo moral da criança ${ }^{7}$, viria completar essa influência, palavras como anomia, heteronomia e autonomia passariam e compor meu texto, minhas aulas e meus projetos pedagógicos.

Essa experiência vivida no Colégio Satélite foi levada para outras instituições escolares, tanto públicas quanto privadas. Senti necessidade de procurar um mestrado para aprofundar o debate, estudar mais e pesquisar algumas situações e inquietações que emergiam na interface da Geografia, da Educação e da Infância. Isso não existia naquele

5PIAGET, Jean. INHELDER, B. A representação do espaço na criança. Porto Alegre: Artes Médicas, 1993.

6PIAGET, Jean. INHELDER, B. A representação do espaço na criança. Porto Alegre: Artes Médicas, 1993

7PIAGET, Jean . O Juízo Moral na Criança. SP: Summus, 1994(1932).

Olh@res, Guarulhos, v. 2, n. 2, p. 301-334. Dezembro, 2014. momento, pelo menos eu não conseguia localizar nenhum programa de Geografia que pudesse abrigar meu projeto. Hoje a gente tem algumas inserções, mas naquele momento não havia, ou eu desconhecia. Tive que tomar uma decisão: ou abandonava tudo o que eu vinha fazendo ou eu realmente começava a caminhar numa pósgraduação na área da Educação, e foi o que fiz, pois ai estavam minhas questões, meus desejos em aprofundar os conhecimento que pudessem contribuir para minha atuação profissional e também para os debates acadêmicos que se intensificavam. Coincidentemente, a UFJF estava montando seu programa de mestrado naquele momento. Houve a seleção da primeira turma e fui aprovado.

Fiz um trabalho não somente ligado à infância. Investiguei no interior da Zona da Mata mineira, como a escola, as crianças e as aulas de Geografia lidavam com as concepções atmosféricas, com os saberes cotidianos sobre o tempo meteorológico, o que circulavam nas narrativas locais. Identificávamos isso na fala das crianças, na fala da comunidade, no currículo e nas aulas. Foi uma longa experiência etnográfica, meses inseridos nas comunidades, ainda fiz mestrado de 04 anos, isso nos possibilitava uma inserção no campo praticamente perdida hoje. Nessa pesquisa, percebemos como adolescentes e crianças daqueles lugares visitados compartilhavam um conjunto de saberes sobre a atmosfera, os quais me eram explicados de forma simples e clara: se a galinha não desce do poleiro ao amanhecer, é sinal de que vai chover; bois, cavalos e cabritos espirrando muito é também sinal de chuva; gato espirrando e se coçando muito é sinal de 
mudança de tempo; cigarras cantando é sinal de tempo bom; em momentos de fortes tempestades não se deve ficar perto de fio de arame, nem de espelho, nem de água; animais de pêlo devem ficar fora de casa, pois isso tudo atrai raio e para prever as condições atmosféricas, basta lembrar os provérbios conhecidos por todos: "Cerração baixa, sol que racha", "Céu pedrento, chuva ou vento", "Vermelha alvorada, chuva mal encarada", "Vermelho céu posto, caris bem disposto." Todos esses conhecimentos sobre os fenômenos da atmosfera, além de outros, são construídos a partir da vivência de alguns moradores e tornamse história da coletividade e essa história vai se consubstanciando; do ensinamento de relatos já existentes, advindos das pessoas mais idosas e de práticas do fazer diário.

Os anos de mestrado possibilitaram também uma longa formação em pesquisa com teóricos pouco estudados na graduação em Geografia. Foi no mestrado que li pela primeira vez os movimentos da escola de Chicago, do Interacionismo Simbólico, da Etnometodologia, conheci o pensamento de Malinovsky, Boas, Mead, Mauss e muitos outros. Lendo o clássico livro de Bogdan e Bliken, nos aportamos nos cinco pontos que eles consideram como traços partilhados procedimentos que buscam se afastar de um fazer pesquisa em bases positivas e nos aproximam das estratégias qualitativas e interpretativas: $1-\mathrm{o}$ pesquisador é o instrumento chave, embora utilize vídeo-tape ou outros materiais, é necessário que ele esteja no campo de trabalho para apreender a realidade a ser estudada; 2- a pesquisa qualitativa é descritiva, os dados são coletados em forma de palavras, fatos. Os dados incluem entrevistas transcrições, notas, fotografias, vídeostapes, documentos pessoais; todos os detalhes e situações são importantes na compreensão; 3- pesquisadores qualitativos estão mais preocupados com o processo do que com o produto. $\mathrm{O}$ pesquisador deve centrar sua compreensão na dinâmica que se processa na vida cotidiana, e isso deverá ser o seu centro de análise; 4- Pesquisa Qualitativa tende a analisar seus dados de forma indutiva. A preocupação do pesquisador não deve ser levantar evidências que provem hipóteses já estabelecidas; o processo deve ser exatamente o contrário: a compreensão e abstração deve partir das evidências levantadas; 5- o significado que os indivíduos atribuem às coisas é de essencial interesse para o trabalho qualitativo. Uma das preocupações do pesquisador deve ser compreender como as pessoas compreendem a si mesmas e o mundo que as cerca. Assumi, a partir daí, com Bakhtin que o ser humano, como sujeito social não pode ser percebido e estudado a título de coisa porque, como sujeito, não pode, permanecendo sujeito, ficar mudo, o conhecimento que se tem dele só pode ser dialógico. Desloquei a noção de "objeto" de pesquisa, para a de sujeitos, indivíduos e informantes qualificados a contribuírem com nossos trabalhos, pessoas portadoras de textos, de narrativas, e que estudar homens, mulheres e crianças fora de seus textos (e contextos) significaria um afastamento da própria ciência humana.

Nesse trabalho do mestrado algumas outras influências também podem ser identificadas. Isso se deve as aproximações que vivenciei aqui em Juiz

Olh@res, Guarulhos, v. 2, n. 2, p. 301-334. Dezembro, 2014. 
de Fora. Tínhamos a profa. Maria Teresa Freitas recém-chegada de seu doutoramento na PUC/RJ, sob a orientação do professor Leandro Konder. E a Maria Teresa fez uma tese sobre a chegada dos pensamentos de Vigotski no Brasil e de Bakhtin. Eu me inseri no grupo de pesquisa dela, na época. Eu que vinha de uma trajetória muito ligada aos estudos de Piaget, comecei a ler um pouco mais os autores da teoria histórico-cultural. Comecei me interessar por outro viés que não estava em meus afazeres acadêmicos. Tivemos a oportunidade de fazer um longo estudo desses autores russos e das suas obras disponíveis no Brasil. No trabalho do mestrado, aconteceu um fato: em uma das comunidades que a gente investigou, coletei muitas falas de crianças reclamando de mudanças para outras cidades. Elas não queriam ir embora do local onde viviam, gostavam de suas comunidades. Não era o foco da minha pesquisa, mas eu guardei esse material. Quando eu terminei o mestrado, isso foi uma coisa que me chamou a atenção. Ao recuperar a fala dessas crianças fui interpretar o que elas diziam. Foi nesse momento que comecei a ver como os processos de migrações as atingiam. Então, eu apresentei um projeto de doutorado no programa de pósgraduação da Universidade Federal Fluminense (UFF), pensando, exatamente, nesse tema: A percepção e a reapresentação espacial de crianças migrantes.

Essa trajetória no programa de doutoramento da UFF consolidou o meu trabalho na infância. Lá eu fui orientado pela Professora Vera Vasconcellos, pesquisadora no campo de Psicologia e uma das precursoras das contribuições da Psicologia histórico-cultural no Brasil e com uma história profunda na sistematização dos movimentos da Educação Infantil. Novamente tive que optar pela Educação, pois não encontrei diálogos envolvendo a infância e a ciência geográfica, pelo menos na perspectiva que propunha pesquisa. Mas o convívio e confabulações com alguns colegas da Geografia (da UFF), em especial com Prof. Rogério Haesbaert foi fundamental. Foram conversas férteis, seus estudos sobre identidade e territórios, os trabalhos sobre a presença dos gaúchos pelo Brasil, em muito me ajudaram. A convergência dessas interlocuções realmente consolidou $\mathrm{o}$ trabalho com o tema da infância. Agradeço sempre ao Rogério os subsídios ao meu texto e minha formação, inclusive a sua participação em minha banca de qualificação, que teve efetiva contribuição nos rumos da pesquisa.

Vale destacar que a Professora Vera Vasconcellos foi uma das fundadoras da Creche da UFF (que completou 15 anos recentemente) $)^{8}$. Como orientadora ela nos instigava a participar em tudo que envolvia seu grupo de pesquisa e de trabalho. Uma das ações era formação para os professores de diferentes redes a partir das vivências que tínhamos na creche. Foi assim que concretizei minha inserção na Educação Infantil, fechei o foco das minhas pesquisas e da minha vida acadêmica. E como não havia debate nenhum da Geografia com/na Educação Infantil, tive que estudar um pouco mais, conhecer os principais teóricos da área, as legislações que emergiam, ou seja, aprofundar-me no

8Maiores informações sobre a Creche podem ser acessadas no site da instituição: WWW.uff.br/creche

Olh@res, Guarulhos, v. 2, n. 2, p. 301-334. Dezembro, 2014. 
próprio campo da Educação Infantil. E fazia isso num momento muito fértil, muitos documentos e materiais estavam sendo produzidos, a transferência das creches da assistência para a educação fomentava um profícuo debate. Foi ai também que me dei conta de como a Geografia falava pouco das crianças. Hoje me pergunto: onde estariam os grumetes que aqui fugiram da esquadra de Cabral, quando de sua chegada às terras que, mais tarde, configurariam o Brasil? E que, se de fato não retornaram, tornaram-se as primeiras crianças migrantes para cá, como aparece descrito ao final da carta de Caminha, escrita em 1500, ao Rei de Portugal. Ou as negras que fugiam da escravidão ou, ainda, eram comercializadas nos espaços urbanos brasileiros? Como nos narra as páginas do jornal o Pharol, que circulava na Zona da Mata Mineira no século XIX. Por que ao fazer os estudos sobre as indústrias no Brasil, não tomei conhecimento sobre a Fábrica de Tecidos Mariângela, de Francisco Matarazzo, localizada em São Paulo, que implementou, em sua produção fabril, máquinas de tamanhos reduzidos, adaptadas ao tamanho das crianças, como forma de aumentar a produtividade dos pequenos? São crianças sem geografias? Sem histórias? Me dava conta que no meio acadêmico, a materialidade das crianças tem tido diferentes representações, essas têm sido "objetos", "sujeitos" de estudo de diversas ciências (Sociologia, Pedagogia, Psicologia, são só alguns exemplos) que as têm percebido ora como portadoras do discurso do outro, ora como portadoras de seu próprio discurso, ora como objetos mudos. Para
Sarmento $(2005)^{9}$, um traço que tem acompanhado as crianças é a compreensão de suas infâncias na perspectiva da negatividade, inscrita desde a palavra latina, é o in-fans, o que não fala e perpetuando-se em outros momentos históricos: é a idade da não razão, é a idade do não trabalho, e mais recentemente, frente as mudanças contemporâneas, que têm alardeado para alguns o desaparecimento da infância (por exemplo, Postman, 1999) ${ }^{10}$ é a idade não-infância. Poderíamos agregar, ainda, às suas reflexões mais uma negatividade: a do espaço e do tempo, a noção de uma infância percebida como sujeitos "a-topos", ou seja, de lugar nenhum, como sujeitos a-temporais, de tempo nenhum. Invisibilidades.

Nesse meio tempo fiz um concurso para a vaga de prática de ensino de Geografia na UFF, a minha entrada nessa instituição significou uma maior aproximação com a creche. Passei a compor o grupo Gestor, a convite da professora Angela Meyer Borba e Dominique Colinvaux. Nesse grupo conheci a professora Maria Vitória Pardal, Deise Nunes e Bernadete Mourão. A ideia da organização da creche se faz por meio de coordenações, mas as decisões são sempre colegiadas. O grupo gestor é um espaço de partilha e encaminhamento de decisões. Eram os próprios professores da universidade que faziam a gestão e o trabalho pedagógico da creche a partir de projetos de pesquisas e extensões. Tínhamos

9 SARMENTO, Manuel Jacinto. Crianças: educação, culturas e cidadania activa in Perspectiva- Revista do Centro de Ciências da Educação. V. 23, Florianópolis, Editora da UFSC, 2005.

10POSTMAN, Neil. $O$ desaparecimento $d a$ infância. Rio de Janeiro: Graphia, 1999.

Olh@res, Guarulhos, v. 2, n. 2, p. 301-334. Dezembro, 2014. 
convênios com os municípios que cediam professores para nós. Em troca, a gente dava formação para todo $o$ município. Foram muitos convênios: Niterói, São Gonçalo, Itaboraí, uma série de municípios e isso acontece até hoje. Isso acabou me colocando muito diretamente no cotidiano com as crianças pequenas. ${ }^{11}$

Nesse itinerário, demarcado pelas preocupações de fundamentações teórico-metodológicas vinculadas às práticas como você se aproximou dos estudos sobre a Infância e chegou a Sociologia da Infância?

Foi durante os estudos de doutoramento. No meio do trajeto de investigação acabei aprofundando muito o trabalho com os fundamentos histórico-culturais. Estava ao lado da Professora Vera Vasconcellos e de outras pessoas muito vinculadas a essas perspectivas teórico-metodológicas. Colaborou nessa aproximação também a participação em muitos dos eventos da Associação Nacional de Pós-graduação e Pesquisa em Educação (ANPED). Além disso, havia o diálogo também com outros pesquisadores como, por exemplo, a professora Sonia Kramer, Angela Meyer Borba, Dominique Colinvaux, Patrícia Corsino, Tânia Vasconcellos, Lígia Aquino, Marisol Barenco de Melo e muitos outros.

Nesse meio tempo a professora Vera conheceu o professor Manuel Sarmento, de Portugal, e o convidou para conhecer à UFF. Ele veio com seus doutorandos e

11Atualmente, a Creche UFF passou a se organizar como Unidade Federal de Educação Infantil e a estrutura foi reorganizada, contando inclusive com professores concursados em seu quadro. numa visita à creche da UFF. Ele achou que as pesquisas no Brasil eram muito vigorosas. Ele acabou se interessando muito em trabalhar de forma compartilhada. $\mathrm{Na}$ época, ele tinha publicado um texto chamado "As culturas da Infância na encruzilhada da segunda modernidade" ${ }^{\prime 12}$. Esse material ganhou muita força por aqui. No campo da educação e da infância, foi um material que se difundiu em larga escala. $\mathrm{Eu}$ me lembro de que quando éramos doutorando e também entre os mestrandos, aquele material era uma referência importantíssima, citação quase obrigatória.

Mais tarde tive oportunidade de ter um contato mais estreito com o pessoal da Sociologia da Infância Inglesa e Francesa, sobretudo pelas atividades que começaram a ser ampliadas no Rio de Janeiro. A Professora Irene Rizzini, da PUC/RJ, coordenadora do Centro Internacional de Estudos e Pesquisa sobre a Infância, organizou evento no CIESPI em que ela chamou o pessoal da Sociologia Inglesa e alguns colegas de Portugal. O grupo dos ingleses liderado por Allison James estabeleceu um contato muito frutífero. Foi nesse momento que começamos, também, a ter colaborações e dessa maneira acessar a uma bibliografia desconhecida. Fomos assim ampliando o contato com Sarmento, com outros pesquisadores portugueses, por exemplo com a professora Manuela Ferreira, com quem até hoje mantemos estreita colaboração e também com o grupo de ingleses e franceses.

$\mathrm{Na}$ UFF, uma colega da creche, Professora Ângela Meyer Borba (que fez uma parte do doutorado dela na França

12 Texto disponível para acesso no blog: www.geografiadainfancia.blogspot.com

Olh@res, Guarulhos, v. 2, n. 2, p. 301-334. Dezembro, 2014. 
com o Gilles Brougère) acabou trazendo muito material da Sociologia de Infância francesa para nós. E ela até hoje participa dos encontros, de Sociologia da Infância de Língua Francesa, que acontecem de dois em dois anos. De fato, ao longo desses encontros nessa escala internacional estabeleceu-se uma interlocução com rebatimentos entre aqueles brasileiros envolvidos com as discussões sobre a infância.

$\mathrm{Na}$ minha chegada à UFF criamos um grupo de pesquisa em Geografia da Infância (Trata-se do Grupo de Pesquisas e Estudos em Geografia da Infância/GRUPEGI$\mathrm{CNPq}$ ), as várias áreas estavam trazendo contribuições para os estudos da infância. A Antropologia tentando pensar a infância, a Sociologia tentando pensar a infância, a Psicologia do Desenvolvimento repensando o papel da infância e pensamos: "-E a Geografia como poderia contribuir? $O$ que teria a dizer para esses estudos?

Esse movimento foi de 2000 para frente. Vale registrar que já havia um grupo ( relacionando o olhar geográfico à Infância) aqui em Juiz de Fora, depois é que oficializamos o grupo lá na UFF, como GRUPEGI. A proposta era exatamente estudar os teóricos da infância e dialogar com as nossas categorias geográficas. E pensar qual seria a contribuição da Geografia para o campo de estudos da infância. É importante destacar que fora do Brasil essa é uma área que já vinha se consolidando. No Brasil como a Sociologia da Infância chegou muito forte, parece que os estudos da infância se reduziam apenas a Sociologia da Infância, mas na verdade, os estudos da infância são uma grande área que abarca outros campos, inclusive a própria sociologia.

$\mathrm{Eu}$ comecei a escrever para alguns colegas da Inglaterra e da Escócia, tentando estabelecer contatos mais sistemáticos, pois a Geografia da Infância nesses lugares está muito sistematizada. Nós começamos a receber os materiais, trocar emails e informações. Nesse meio tempo me filiei a Royal Geographical Society no Grupo de trabalho Geographies of Children, Youth \& Families Research Group, isso permitiu ampliar nossas trocas. Receber e ler periódicos e textos. Por exemplo, A Childhood, uma revista especializada em Infância, tem números especiais só sobre Geografia da Infância. Começamos, então, a trazer para o grupo alguns referenciais que a gente não tinha aqui. O grupo ficou nessa interface: a gente continuava estudando a teoria históricocultural, aprofundando seus postulados cada vez mais. Mas lendo também os outros teóricos da infância. Textos como: JAMES, A.; PROUT, A. Constructing and Reconstructing Childhood: Contemporary Issues in the Sociology of Childhood. Basingstoke: Falmer Press, 1990; PROUT, A. The Future of Childhood: Towards the Interdisciplinary Study of Children. London: Falmer Press, 2005; PROUT, A.; JAMES, A. Constructing And Reconstructing Childhood: Contemporary Issues in the Sociology of Childhood. London: RoutlegeFalmer, 1990; PROUT,. The Body, Childhood and Society. London : Macmillan, 2000; PROUT, Culture-Nature and the construction of childhood. The international handbook of children, media and culture, Editors: Drotner, K. and Livingstone, S., Los Angeles ; London: Sage, 2008; SARMENTO,

Olh@res, Guarulhos, v. 2, n. 2, p. 301-334. Dezembro, 2014. 
Manuel Jacinto. Crianças: educação, culturas e cidadania activa in Perspectiva- Revista do Centro de Ciências da Educação. V. 23, Florianópolis, Editora da UFSC, 2005; SARMENTO, Manuel Jacionto; MARCHI, Rita de Cássia Marchi. Radicalização da infância na segunda modernidade: Para uma Sociologia da Infância crítica. Configurações, 4. 2008 (disponível em: file:///C:/Users/Jader/Documents/Meus\% 20documentos/Jader/Textos\%20Sociolo gia $\% 20 \mathrm{da} \% 20 \mathrm{inf} \% \mathrm{C} 3 \%$ A2ncia/configur acoes-498-4-document-sans-titre.pdf); QVORTRUP, Jens. Nine Theses about "Childhood as a Social Phenomeno". Eurosocial Report Childhood as a Social Phenomenon: Lessons from an International Project, n. 47, 1993, p. 1118 e muitos outros eram leituras obrigatórias.

Nós tivemos a oportunidade de levar o professor Willian Corsaro à UFF para fazer um trabalho conosco. Foi um encontro muito significativo, pois tivemos a chance de tecer considerações sobre seus trabalhos, dialogamos sobre a cultura de pares, sobre suas críticas ao processo de socialização das crianças, sobre etnografia com crianças, sobre as dificuldades e empecilhos da entrada em campo, a noção que ele traz de adulto atípico e sobre seu conceito mais conhecido, o de reprodução interpretativa. Aos poucos amadurecemos a ponto de organizar um pool de grupo de pesquisa lá da UFF. Juntamos o grupo da creche, o meu grupo e os de outros colegas, e começamos a tentar ver, a mapear um pouco esses estudos que estavam aparecendo da infância. Tínhamos o Núcleo Multidisciplinar de Pesquisas, Extensão e Estudos de crianças de 0 a 7 anos, o NUMPEC, onde sempre convergiam nossas inquietações e ações de pesquisas. Foram também ricos momentos de aprendizagens.

Nesse tempo, acabamos criando um evento, que chamamos de Seminário de Grupos de Pesquisas sobre Crianças e Infâncias, o GRUPECI. Essa inspiração começou numa conversa com a profa. Léa Stahlschmidt Pinto Silva, que era professora da Educação Infantil aqui na UFJF. Em conversas ela comentou que gostaria de fazer um evento de Educação Infantil aqui em Juiz de Fora antes de se aposentar. "Decidimos pensar em alguma coisa de grupos de pesquisas". Esse era um debate que vinha aparecendo na ANPED. No primeiro momento, pensamos uma coisa grandiosa: "-Vamos fazer um encontro internacional, chamar vários expoentes da área." Como as verbas estavam escassas, nós fomos reduzindo, reduzindo... Nesse ínterim criamos o GRUPECI, fizemos uma chamada para que os grupos de pesquisas interessados pudessem compartilhar seus trabalhos, a gente achou que fosse ter uma versão só, que seria algo pequeno. Todavia vieram pesquisadores de Portugal, vieram pesquisadores de outros centros, de várias partes do país, enfim vieram muitos investigadores. $\mathrm{O}$ evento deu super certo e já está na quarta para quinta versão. Tornou-se um evento consolidado na área. $\mathrm{O}$ que era para ser um encontro mais local acabou tendo uma força muito grande. Então, isso virou um espaço especial de troca dos grupos e também de decisões políticas.

Como já dissemos o nosso grupo de pesquisa Geografia da Infância vem tentando dialogar com as proposições da teoria histórico-cultural e, com os teóricos das outras áreas da infância e da

Olh@res, Guarulhos, v. 2, n. 2, p. 301-334. Dezembro, 2014. 
Geografia. É interessante ressaltar que ao refletirmos sobre essas questões, ao pensarmos uma Geografia para crianças e, principalmente, e o que mais nos interessa, uma Geografia com as crianças, nos deparamos com uma interface de trabalho nas instituições. Se por um lado há essa preocupação com os teóricos, por outro há essa possibilidade de atuação com as questões práticas da Educação Infantil em diversos contextos onde somos chamados a estar.

$\mathrm{Na}$ Creche da UFF, por exemplo, por ser um espaço de referência de pesquisa, os trabalhos que a gente desenvolveu lá apresentavam muito essa preocupação: a Geografia na Educação Infantil, a Cartografia na Educação Infantil, a Geografia com Crianças, a Cartografia com Crianças e outros, são sempre fundamentos teóricos que se intensificam e relacionam com práticas do cotidiano. São assim também com nossos bolsistas de PIBIC, o próprio PIBID é outro exemplo. No ano de 2012 conseguimos organizar um subprojeto e inserir nesse programa de formação de professores, apresentando um projeto na área de Educação Infantil. Eu não sei se tem outro no Brasil, porque o PIBID, inicialmente, estava direcionado ao ensino fundamental e médio. Nessa proposta que foi aprovada pela CAPES houve uma colaboração com a coordenadora da área da Pedagogia, Profa. Marisol Barenco de Melo que selecionou seis bolsistas para que pudéssemos, dessa maneira, fazer pesquisas nas creches de Niterói. Eu não estou mais na coordenação em função da minha vinda para a UFJF. Mas ficou um diálogo, ficaram interfaces importantes.

O PIBID é um programa que procura estreitar as relações entre universidade e escola pública no que diz respeito a formação de professores. Nossa experiência como professores de fundamentos teóricos e práticos do ensino de História e de Geografia em um curso de licenciatura como o de Pedagogia cujo projeto pedagógico tem como um dos pilares a residência pedagógica tem desvelado várias questões, em especial aquelas referentes as invisibilidades das crianças dos primeiros anos da escola básica e também sobre a delicada questão das especificidade de formação docente - leia-se educadores de crianças pequenas e dos anos iniciais do ensino fundamental, dialogando com a escola. Por essa modalidade de estágio da UNIFESP, na residência pedagógica, os grupos se dividem em Educação Infantil, Ensino Fundamental, Educação de Jovens e Adultos e Gestão. Como você vê essas aproximações dos aportes da Geografia e da História para incrementar os estudos da Infância durante a formação do professor na graduação? Como funciona isso nas instituições em que atuas? Como é esse diálogo?

$\mathrm{Na}$ UFF os alunos do curso de Geografia, que serão professores dos anos finais do ensino fundamental e ensino médio, têm as matérias pedagógicas e orientação de estágio na Faculdade de Educação.

$\mathrm{Na}$ Faculdade de Educação essa formação se dá em vários sentidos. Por exemplo, no caso da creche, uma das ações que praticávamos muito era a formação continuada dos professores dos municípios. Dessa maneira a creche tornava-se um espaço de pesquisa,

Olh@res, Guarulhos, v. 2, n. 2, p. 301-334. Dezembro, 2014. 
ensino e extensão. Os professores que vinham dos municípios, ficavam um ano atuando lá dentro, era uma formação no próprio cotidiano, eram formados dentro da creche. Era algo trabalhoso, porque todo ano chegava gente nova, e você tem que ir iniciando o processo sempre. E além das questões políticas que se envolviam, porque mudava a prefeitura, por exemplo, tinha que reafirmar o convênio, às vezes ficava um mês sem professor.

Só que além desse grupo que chegava para a formação, a creche também é um espaço de extensão e pesquisa. E na UFF, a extensão é organizada, em geral, a partir de planos amplos. Existia um que se chamava Projeto Creche UFF, que envolvia várias disciplinas. A Geografia, num primeiro momento, não estava inserida. Esse projeto reunia alunos da universidade que queriam conhecer um pouco mais a Educação Infantil ou que precisavam estagiar por lá. Eles entravam na creche para poder trabalhar com projetos. Inicialmente, as áreas mais clássicas Fonoaudiologia, Nutrição, Medicina, da Enfermagem e do Serviço Social se faziam presentes. A professora Dominique Colinvaux e Ângela Meyer Borba me convidaram para inserir um projeto de Geografia e um de Cartografia com Crianças.

Quando eu comecei a atuar, procurei abrir espaço para os alunos da Geografia. Os alunos eram muito tímidos em relação à infância. Eles achavam que ali não era o espaço que a Geografia tinha que atuar. Foram muito resistentes no início.

\section{Vem daquela lógica da assistente social? Na verdade, não da educação, mas de um espaço para a criança que}

você teria mais o direito da mãe do que da criança. Daí, não tem...

Eu conversava demais com os alunos, tínhamos encontros e reuniões freqüentes de estudos. A resistência deles era em perceber as crianças como sujeitos que produzem conhecimentos significativos. Escutava narrativas como: crianças não têm abstração, para a criança tem que pensar no lado do concreto e tal. Era sempre um discurso adultocentrado e com a marca do "para a criança". Foi muito importante a entrada, de alguns alunos. Primeiro, que os alunos da Geografia começaram a chegar à creche. E isso trouxe um movimento interessante, porque a gente começou a ter os alunos buscando a pósgraduação depois na área da Educação Infantil. E passaram a compreender as crianças com outras perspectivas, palavras como agency (agência), protagonismo, participação infantil passaram, a fazer parte de seus repertórios. Isso para nós foi uma grande mudança.

Consolidou-se um movimento de reconhecimentos que o espaço da Educação Infantil era um espaço também de formação e de pesquisa. E uma coisa que me chamava muita atenção, era a surpresa dos alunos da Geografia quando começavam a lidar com as crianças reais. Porque chegavam com uma criança abstrata, um sujeito totalmente desvinculado da realidade, de um imaginário construído pela própria academia. E quando vinham para a creche e começavam a lidar naquele cotidiano, eles se davam conta que a conversa era outra. E isso era muito interessante, porque, aí sim, a gente via de fato uma transformação na forma de ver as crianças, de agir com elas. No

Olh@res, Guarulhos, v. 2, n. 2, p. 301-334. Dezembro, 2014. 
caso, dentro do nosso currículo das práticas, nós fazíamos a sugestão, não havia uma obrigatoriedade do estágio desses alunos ser realizado na Educação Infantil.

Quando nós tivemos a reformulação na Prática de Ensino IV, nós vimos que a Geografia deixava uma série de coisas de fora na formação do professor. A gente viu que a questão não era só infância, por exemplo, a questão de gênero, questão de sexualidade. Esses temas que são recorrentes na educação, a Geografia não discutia. Passamos a organizar um conjunto de atividades que permitiam os acadêmicos fazerem estágio em espaços alternativos, a ter contato com temas pouco presentes em suas formações. E dessa maneira organizamos palestras, eventos e seminários em que os graduandos vinham e debatiam a partir de convidados diários Por exemplo, se tínhamos uma colega docente que trabalhava com Educação Inclusiva, ela vinha, fazia um debate sobre Educação Inclusiva, trazia os materiais que trabalhava. Eram materiais para a gente problematizar e debater em sala. E mais tarde, os acadêmicos iam a alguma escola ou outra instituição, conhecer o trabalho. A gente foi fazendo esse movimento. Colocamos a infância dentro desse debate estreitando os diálogos entre a Geografia e infância.

Nós organizamos um livro contando um pouco essa experiência e a gente convidou cada professor para falar de um desses temas que trabalhou conosco. Foi muito rico. Foi dinâmico porque os alunos percebiam muitos temas que a Geografia deixava de fora do debate.

Outro movimento significativo são os colóquios do grupo de pesquisa. Chamamos pessoas de fora, que possuem interfaces com o grupo, com temas pertinentes ao momento vivido, e convidávamos todos interessados em participar. Percebemos que a questão da infância ainda é uma coisa que se conhece pouco, essa ideia da criança produzir conhecimento e produzir a sociedade é algo que ainda precisa ser muito discutido.

Há uma história vivida na Creche UFF que ilustra o que estou dizendo. No projeto político pedagógico está explicitado a proposta de um trabalho por projeto, por currículos dialogados com o contexto das crianças. E tivemos um projeto sobre dinossauros. Nesse projeto as crianças passaram a se interessar por questões geológicas. Nós inserimos muitas contribuições da Geografia na busca de responder as questões levantadas pelas crianças. Os alunos da Geografia que foram conhecer o trabalho ficaram extasiados, porque eles não imaginavam o que ocorria. Eram com crianças do G2 (uma forma de agrupamento), crianças de quatro anos de idade. Eles ficaram discutindo as teorias geológicas, as eras...tal era a capacidade de dialogar com isso.

Então, esse é outro dado também, dependendo do projeto que está sendo desenvolvido na creche, eu fazia os alunos passarem por lá, fazer visita, darem uma olhada para poder acompanhare ajudar a gente a trabalhar com os meninos e meninas da instituição. Formalmente, no nosso currículo, o espaço que aparecia era só na Prática de Ensino IV, mas era também um tema dentro de um conjunto de temas. Minha presença lá na Creche e em outras que desenvolvíamos trabalhos facilitavam todo esse intermédio, tornava bem possível a presença dos alunos e alunas da Geografia.

Olh@res, Guarulhos, v. 2, n. 2, p. 301-334. Dezembro, 2014. 
Eu vou te dizer, fico muito feliz hoje por ver que há muita gente procurando o grupo, procurando a seleção de mestrado e doutorado. Inicialmente, quando eu comecei a abrir vaga de pós-graduação nessa área, era mais o pessoal da Pedagogia, da História, muita gente da Psicologia... Hoje, por exemplo, os meus orientandos, uma grande parte deles é da Geografia, inclusive de doutorado e de várias partes do Brasil e exterior. E também é significativa a busca de colegas para estágios de pós-doutoramento.

Dentro do curso da Pedagogia, o diálogo, então, funciona um pouco mais na formação da graduação?

Ele funciona, porque somos nós quem ministramos os cursos, todos envolvidos com essas preocupações a respeito dos vínculos possíveis de serem estabelecidos entre a Geografia e a Infâncias. Vale o registro de que lá na UFF não há a separação História e Geografia. A opção é a do trabalho integrado identificado como Ciências Sociais. Inclusive, na última reforma curricular do curso de Pedagogia, se debateu muito isso. $\mathrm{O}$ resultado foi a manutenção, o grupo decidiu que deveria manter as Ciências Sociais.

Nas suas colocações várias das questões que nós tínhamos selecionado de uma forma ou de outra acabaram sendo contempladas. Temos uma leitura da infância na perspectiva da História e da Geografia expressas nos Cadernos de Residência Pedagógica da UNIFESP. O que percebemos a partir de nossa experiência como preceptores na residência é que tanto o professor formador como as residentes necessitam da Geografia e da História para pensar a infância. Mas do ponto de vista teórico é diretamente a questão do espaço que entra como elemento fundamental na percepção das infâncias. De ver as diferentes infâncias. Gostaríamos que você falasse um pouco mais a respeito da questão do conceito de infância e de como o espaço é uma dimensão importante no trabalho do professor.

Penso que temos que situar um pouco essa conversa no campo de Estudos da Infância. Nos anos 80, século passado, e nos anos vindouros, na Europa, inicia-se um processo de rever os conceitos e teorias tradicionais vinculadas à forma de conceber as crianças, movimentos na França, na Inglaterra e em outros espaços vão evidenciar a necessidade de um novo debate para a infância. Nomes como Régine Sirota. Julie Delalande, Alan Prout, Adrian James, Jenks, Qvortrup, Sarmento, o próprio Corsaro e claro outros, começam a levar em conta que as teorias clássicas sobre a infância não estavam mais dando conta. E aí, começa a haver a publicação de novos materiais e textos que irão contribuir para uma nova virada epistemológica.

Há um livro de Alan Prout, por exemplo, escrito em coautoria com Allison James, nomeado de Constructing and Reconstructing Childhood ${ }^{13}$ que teve um grande impacto na nova forma de se compreender a infância e para a

13PROUT, A.; JAMES, A. Constructing And Reconstructing Childhood: Contemporary Issues in the Sociology of Childhood. London: RoutlegeFalmer, 1990.

Olh@res, Guarulhos, v. 2, n. 2, p. 301-334. Dezembro, 2014. 
emergência da Sociologia da Infância, como um novo campo de estudos. Ai são defendidas algumas as teses que se tornaram seminais nos estudos com crianças. Esse livro até hoje não está publicado no Brasil, mas como ele foi muito citado em trabalhos acadêmicos, acabou que as ideias dele ficaram muito presentes: são críticas à lógica de você pensar a infância numa perspectiva somente biológica, assumem a infância como uma construção sociocultural e histórica e, portanto, plural. Eu não posso falar em uma infância, eu tenho que falar numa pluralidade de infâncias, como uma pluralidade de mundos que existem. Então, esse é um ponto importante, porque ele vai tentar fazer o rompimento dessa lógica naturalista. É, claro, uma crítica muito direta, ele não fala isso explicitamente, à Psicologia do Desenvolvimento. Porque na verdade a Psicologia do Desenvolvimento era a grande área que sustentava todos os debates com as etapas, com essas questões, e de uma forma universal e natural. Então, todas as crianças do mundo, independente das suas culturas, dos seus contextos, passariam por aquelas etapas. Eles inclusive vão assumira existência de uma fase présociológica da infância marcada por concepções que se tornaram consolidadas, como a concepção inocente, que é a infância baseada, por exemplo, na lógica do Emílio, do Rousseau. A lógica do Durkheim de socialização, também será questionada. E outros, como, a visão estruturalista da Psicanálise.

Em cima disso, eles começam a separar os conceitos de infância e criança, passam a alertar que não são sinônimos. Porque a infância é sempre uma representação, uma construção, uma forma de pensar a criança, um lugar social. E aí, a gente começa a debater, inclusive, o que vem a ser a criança porque, afinal de contas, os estatutos clássicos começaram a ruir.

E o que a gente percebe no caso da Geografia da Infância? Que esse livro e várias outras publicações, na Inglaterra, Escócia e de outros localidades, irão impactar muito os estudos da Geografia da infância. Porque você começa a pensar: se existe uma diversidade de países, de contextos geográficos, então há efetivamente uma quantidade de lugares ocupados pelas crianças. E esses lugares ocupados são também infâncias e não podemos falar apenas na infância canônica proposta pela perspectiva da temporalidade do desenvolvimento, marcadas por perspectivas topológicas, projetivas $\mathrm{e}$ euclidianas, por exemplo.

Outro postulado que esse movimento irá apontar refere-se a dimensão metodológica. Ao assumirem que a infância é plural e é uma construção histórica, o melhor caminho para se pesquisar as crianças seria a etnografia. Os novos estudos da infância apontam para e etnografia como um modelo clássico de pesquisa com as crianças, e de fato isso aconteceu em muitos estudos. Assumir a etnografia com criança retoma-se a tese clássica do Willian Corsaro, por exemplo, porque quando ele cria a ideia da cultura de pares, ele traz a proposta de que existe uma cultura que é própria entre as crianças. E a melhor forma de você acessar essa cultura é também pela etnografia. No nosso grupo estamos cartografando a trajetória da Geografia da Infância no mundo, suas origens, seus teóricos, seus fundamentos, percebemos,

Olh@res, Guarulhos, v. 2, n. 2, p. 301-334. Dezembro, 2014. 
por exemplo, que essa é a metodologia recorrente.

O Jens Qvortrup é outro autor do Norte da Europa, e ele vai lançar um material também de grande importância. É uma pesquisa encomendada por vários países europeus, que depois seria publicada em um texto, que também, infelizmente, não tem em português, que chama-se: "-As nove teses sobre a infância". E que, na verdade, reforça essa situação da infância enquanto categoria social. E cria ali, de forma mais explícita, o conceito geracional. A questão não é só na infância que se desloca e adversa no espaço, mas também você tem uma infância que adversa na temporalidade. Porque você tem o conceito de geração, que marca as infâncias da sua perspectiva histórica. Ele vai trabalhar também ideia de estrutura, pois assume que apesar de você ter essa infância plural, você tem também uma infância que é atravessada pelas estruturas sociais. Agrega ainda ao debate a questão de classe econômica, a questão de gênero, e outras questões que seriam fundamentais. Há muitas outras obras que impactaram, mas precisaríamos de diversas horas de entrevistas para isso.

No caso da Geografia, nesse levantamento que estamos fazendo, o que a gente percebe? Os primeiros estudos, que começam a falar sobre a infância e uma Geografia da Infância, são dos anos 1970. Eles são muito embasados nas obras de Piaget. O texto de Yi Fu Tuan, Topofilia é um livro que também impacta muito a nossa área e também será muito usado por outras campos de conhecimentos. Em $O$ Espaço e Lugar, ele inclusive destina um capítulo para as crianças, que também será muito apropriado nos estudos da
Geografia da infância. O livro " $A$ Região, espaço vivido" de Armand Fremont, "A imagem $d a$ cidade" de Kevin Lynch também serão materiais referenciados, esse último inclusive no campo da Cartografia infantil, com os Mapas mentais.

O texto do Sarmento citado anteriormente, propõe que se busque compreender e levantar oque ele chamou de a "gramática da infância". Quando ele fala em relação a levantar à gramática da infância, ele começa a trazer a ideia de que você deveria trazer e buscar a leitura de como as crianças vivem o mundo na ótica delas. Ou seja, ele defende a ideia da cultura de pares e que você deve, situar os estudos, na compreensão das formas que as crianças leem o mundo. Se você quer conhecer como estudar a criança, você tem que conhecer como a criança compreende o mundo. E isso, então, teve uma força muito grande nas pesquisas. Sarmento faz outras propostas mais recentes, ampliando o debate para uma sociologia mais crítica.

No caso do nosso grupo, esse é um dos focos que perseguimos, temos diversos projetos acontecendo (ver mais detalhes em: www.geografiadainfancia. blogspot.com), um deles é o Lógicas e Autorias Infantis, coordenado em conjunto com a professora Marisol Barenco. Achamos fundamental dialogar com as lógicas das crianças, reconhecer que suas expressões no mundo não são marcadas por ausências, por um vir a ser, mas são situações presentificadas, bases para pensarmos o protagonismo infantil.

Além disso, já expressei que para mim que Piaget teve uma grande influência ao corroborar na noção que as crianças têm uma lógica própria de pensar o mundo, diferenciada dos adultos. Mas quando eu

Olh@res, Guarulhos, v. 2, n. 2, p. 301-334. Dezembro, 2014. 
fiz tese de doutorado, quando fui trabalhar com as crianças migrantes, eu tive muita dificuldade em dialogar com Piaget, porque as crianças migrantes não viviam aquelas categorias espaciais como Piaget falava. Num primeiro momento, tive a tendência a reconhecer essa situação como uma dimensão da falta, faltava algo nas crianças que migravam. Mas, sem crer muito nesse postulado, fui mergulhar no Vigotski, em busca de outras respostas. E reconheci nesse autor muitas leituras que contribuem com a Geografia da Infância. No grupo estamos fazendo um esforço para estar em acordo com os estudos mais contemporâneos, do próprio Vigotski e outros pensadores da escola russa, da própria Sociologia da Infância e dos demais campos de Estudos da Infância e, claro da Geografia da Infância.

No caso da Teoria Históricocultural, tivemos a chegada, por concurso público, da professora Zoia Prestes, na Faculdade de Educação da UFF que na sequência se incorporou ao nosso grupo. Hoje ela coordena o NUTHIC. A Zoia e sua família moraram muitos anos em Moscou, devido ao exílio. Lá ela se formou em Psicologia. E quando voltou para o Brasil, se deu conta de como haviam equívocos nas traduções dos livros do Vigotski. Ela conta um pouco disso no livro "Quando não é quase a mesma coisa - traduções de Lev Semionovitch Vigotski no Brasil" - resultado de seus estudos de doutoramento.

Hoje a gente tem maior clareza dos problemas das traduções em especial desse pensador, cujas ideias chegaram no período da Guerra Fria, via as traduções americanas. Com a Zoia temos o privilégio de poder contar com as leituras diretas dos escritos do próprio Vigotski. Temos dedicado no grupo momentos de traduções de material inédito para o Brasil. Além disso, temos tido a possibilitar de trazer ao Brasil colegas das instituições de ensino do Leste Europeu e ao mesmo tempo fazer visitas por lá. Por exemplo, no ano passado (2011), a gente convidou para participar do colóquio do GRUPEGI, uma professora que falou sobre neurociência e neuropsicologia, que foi orientanda do Luria. Assim, temos feito um trabalho direto muito bom com esses grupos de Moscou. Então, a gente tem conseguido acessar nesses debates alguns conceitos, alguns materiais inéditos, coisas que não circulavam muito no Brasil, isso, tem nos ajudado muito a cada vez mais consolidar nossos trabalhos.

\section{A imagem da infância, a primeira leitura da infância. A Geografia da Infância.}

E repensar a questão da infância, por aí, pela Geografia da Infância, isso é: uma tentativa de ler a infância à luz da espacialidade, como a Geografia faz sempre nas instâncias sociais. Compreender à luz das expressões espaciais as crianças e as infâncias, esse é um dos nossos desejos, mas também é, compreender a geografia das crianças, suas linguagens espaciais, o protagonismo geográfico infantil e suas potencialidades de criação e transformações.

As pesquisas feitas no exterior apresentam trabalhos bem mais consolidados e também apresentando múltiplas possibilidades de atuação,

Olh@res, Guarulhos, v. 2, n. 2, p. 301-334. Dezembro, 2014. 
como é o caso da Grã-Bretanha e em outros países europeus. Lá existem muitos trabalho de geógrafos em parques infantis, áreas destinas às crianças nas cidades, em shopping centers, tendo como referência como as crianças se comportam. São geógrafos pensando diretamente as questões das crianças e infâncias. Precisamos ampliar isso no Brasil, esse tem sido uma das nossas buscas.

Você mantém uma colaboração com um grupo de pesquisa da Alemanha, você pode contar um pouco sobre isso e como se relaciona ao seu pósdoutorado e de sua pesquisa?

A partir das pesquisas desenvolvidas no GRUPEGI tivemos contato com um professor chamado Bernard Fichtner e com um grupo na Alemanha, que trabalhava com narrativas biográficas. Eles se localizam na cidade de Siegen, distrito SiegenWittgenstein, no estado da Renânia do Norte-Vestfália, foi nesse local que me acolheram para o pós-doc. O estágio pós-doutoral foi desenvolvido no International Educational Doctorate Program (INEDD), da Universidade de Siegen. O INEDD é apoiado por dois centros: O Centro de Planejamento e Avaliação de Serviços Sociais ("Zentrum für Planung und Evaluation Sozialer Dienste“ - ZPE) e o Centro de Siegen para a Pesquisa da Infância, da Juventude e Biográfica (Siegener Zentrum für Kindheits- Jugend- und Biografieforschung / SiZe). Foi nesse último que atuei. É um dos maiores centros de biografias da Alemanha e da Europa. É muito interessante esse centro, porque eles recolhem uma infinidade de materiais. Fica em um antigo castelo no centro da cidade que, segundo descrevem, pertenceu à família de Nassau, o centro ocupa praticamente um andar inteiro. Eles desenvolveram uma metodologia de trabalho, para poder capturar essas memórias, que eles chamavam de mapas narrativos (Narrative Landkarten). E eu fiquei muito curioso para poder conhecer esse material, já o nosso grupo estuda questões metodológicas ligadas ao espaço. Quando o professor Fichtner esteve aqui, ele veio com outros colegas da equipe do INEDD e nos conhecemos, ai aconteceu o convite para o trabalho por lá.

\section{De pesquisa qualitativa.}

Em 2005, eu e a professora Tânia Vasconcelos. Tínhamos acabado de lançar um livro, um pequeno ensaio chamado "Geografia da Infância reflexões sobre uma área de pesquisa". Um livrinho fininho, que esgotou, não foi mais re-editado. Foi um ensaio rápido, encomendado para sair na Anped daquele ano. $\mathrm{E}$ nós fizemos uma apresentação aqui, num evento de pesquisa qualitativa que envolveu a UFJF e Siegen Universität. O grupo da universidade alemã assistiu nossas colocações e eles acharam muito interessante, pois tinha a ver com o que eles trabalhavam lá na Alemanha. A gente começou a conversar, trocar ideias e foi ocorrendo um contato cada vez mais ampliando.

Interessou-me ouvir um pouco mais essa ideia dos mapas narrativos que eles estavam desenvolvendo por lá. Nosso grupo estava em plena reflexão sobre uma metodologia capaz de cartografar as

Olh@res, Guarulhos, v. 2, n. 2, p. 301-334. Dezembro, 2014. 
vivências espaciais infantis, debatíamos conceitos, nomes, adjetivos, estratégias, falávamos em croquis territoriais, em mapas mentais, em cartografias simbólicas, era uma intensa discussão, inclusive com outros grupos da própria universidade. E aí, a partir do convite do Professor Bernard Fichtner fui fazer o pós-doc por lá. Fui muito bem recebido por ele e pela professora Imbke Behnken, que na verdade se dedicava mais ao trabalho com os mapas narrativos. Passava quase todas manhãs na Universidade vendo o trabalho com essa metodologia, que eles inclusive reconheciam como uma etnografia visual. Eu pude conhecer coisas muito interessantes que eles faziam, pude ler muitas monografias que tinham sido confeccionadas a partir dessas propostas. A ideia básica era, a partir de desenhos e de narrativas, você tentar capturar nos indivíduos, nos sujeitos, o que eles chamam de lebenswelt, ou seja, o mundo vivido. Os fundamentos estavam nos postulados de Alfred Schultz. Por isso eles não reconheciam essa ação como mapas mentais. $\mathrm{Eu}$ fiquei fascinado porque eu tive acesso às memórias de infância da guerra, da Segunda Guerra Mundial, narrativas fantásticas e dramáticas. A metodologia serve tanto para pessoas mais novas, quanto para pessoas mais velhas. Por exemplo, eles estavam pesquisando muito pessoas que tiveram a sua infância na guerra $\mathrm{e}$ tentando lembrar, a partir desses mapas narrativos, os espaços em que eles vivenciavam, que mundo era aquele vivido pelas crianças.

$\mathrm{Na}$ Alemanha, pude conhecer também o sistema de formação de professores que é bem diferente do nosso. Lá eles têm a Faculdade de Educação, e em todos os cursos de licenciatura, você faz toda a trajetória na prática. $\mathrm{Eu}$ fui trabalhar com $\mathrm{O}$ departamento de Psicologia da Faculdade de Educação. Lá os alunos têm que escolher duas licenciaturas, eles se graduam em duas licenciaturas. E muito deles acabam optando Geografia e História, fazendo essa parceria. Então muitos alunos de História e Geografia, acabavam, nas monografias de graduação, trabalhando com os mapas narrativos. Só que a base teórica, como já mencionei, está assentada em Alfred Schutz. Então assim, eles trabalham muito com a questão da hermenêutica. Foi muito interessante.

Quando eu voltei, nós fizemos uma experiência, lá no João XXIII. O Bruno pode contar um pouco como nós adaptamos um pouco a lógica dos mapas narrativos

Bruno: “- $\mathrm{Na}$ verdade, foram duas entradas. Nosso grupo aqui mapeou uma pesquisa, com crianças, para cartografar o centro de Juiz de Fora. E, ao mesmo tempo, a gente também queria ver como que isso poderia de alguma forma, ser traduzido na escola, na produção cartográfica escolar. Então a gente trabalhou dentro um pouco dessa perspectiva, nessas duas frentes".

Jader : “- na época vocês levantaram quantos mapas lá?"

Bruno: - Na escola, no trabalho do projeto pedagógico, foram mais de 90 mapas. Aproximadamente 90 mapas, na pesquisa foram quantos, Cassiano?

Cassiano: "Doze. Nós trabalhamos com duas escolas diferentes, com crianças de 10 anos uma escola estadual, e a escola João XXIII, foram 12 mapas".

Jader: "- nós seguimos basicamente o que eles faziam lá na Alemanha. Assim,

Olh@res, Guarulhos, v. 2, n. 2, p. 301-334. Dezembro, 2014. 
tentando ver como que as crianças faziam os registros. Só que aí, no próprio grupo começamos a conversar sobre essa metodologia e o que nos fundamentava, constatamos alguns curtos circuitos epistemológicos. Travamos discussões sobre teoria, estado cultural, fundamentos na teoria histórico-cultural, etc. Nesse sentido, a gente encontrou um conceito nos postulados de Vigotski, o conceito de perejevania, tomando como referência essas novas traduções apontadas por Zoia, essa palavra significa vivência e um outro conceito, que é o conceito ligado a ela, sredá, que significa meio. Então achamos dois conceitos, básicos que nos acompanhariam no debate da Geografia da Infância. Dessa maneira nós vimos que o conceito de vivência, era um conceito que tinha muito a ver com o que estávamos trabalhando no grupo de pesquisa, pois Vigotski reconhece que Vivência é a unidade do indivíduo com o meio.

Para o autor há uma união, uma unidade. Você tem o meio em que a criança vive e tem a própria criança. $\mathrm{O}$ que faz essa unidade é a vivência, é esse conceito, com fortes referencias em Espinosa. A professora Zoia faz uma crítica a partir disso, dizendo que isso é o exemplo de que o Vigotski não é sócio-intervencionista, como muito se propaga por ai. Porque ele não trabalha com a ideia de interação, mas sim de unidade. Essa ideia de que você não tem escolha, de que você está no meio o forma e é formado. Isso é um processo.

A gente pensou como poderia usar o conceito de vivência para os nossos trabalhos, porque tem tudo a ver. Afinal de contas, quando nós fomos ver as traduções e aprofundar no conceito de sredá, percebemos que a noção de espaço geográfico cabe muito bem ai. Então a gente viu que a ideia de espaço geográfico e sredá teria muita aproximação, então seria para nós uma boa entrada também.

Estamos experimentando, fazendo o que a gente vem chamando de mapas vivenciais. Inspirado nos mapas narrativos, mas com diferenças epistêmicas, tentamos cartografar a vivência das crianças. Então esse tem sido nosso referencial teóricometodológico, nosso tom no trabalho e nossas estratégias de pesquisa. Essa tem sido a nossa Geografia da Infância.

$\mathrm{O}$ estudo e a busca tem sido constante, por exemplo, no ano passado (2012) fizemos um estudo do texto que a professora Zoia traduziu, "A imaginação e criação na infância". O estudo se deu como uma disciplina no PPGE da Universidade Federal Fluminense. $\mathrm{O}$ curso foi conduzido por mim, pela professora Zoia e pela Professora Marissol Barenco de Melo. Encontramos alguns conceitos aqui também, que pareceriam periféricos nos escritos do Vigotski, mas que ao ser entendido na totalidade da obra ganhariam outro sentido. Por exemplo, Vigotski vai desenvolver a ideia de que a criança recebe um mundo pré-herdado, um mundo pré-existente, um meio préofertado pelas gerações anteriores, se a gente for falar da nossa área seria, algo como a existência de paisagens que acolhem as crianças, não são espaço esvaziados de vida. Então a criança chega nessas paisagens, já interpreta esse mundo ofertado. Ocorre o que chamamos de re-elaboração criativa, então não é aquela lógica de internalização tradicional que nós estamos acostumados a pensar. $\mathrm{O}$ mundo

Olh@res, Guarulhos, v. 2, n. 2, p. 301-334. Dezembro, 2014. 
por si só já é um mundo da sociedade, da cultura. Já são paisagens préexistentes culturalmente forjadas (por isso são paisagens no sentido geográfico) e a criança interpreta a partir dessas dimensões. Então para a criança já é um processo de interpretação e de criação dessa interpretação, é sempre a criação do novo, do inexistente.

Isso é a reelaboração criativa. Vigotski vai dizer que a criança nas suas brincadeiras pega os elementos da cultura e transformar esses elementos no novo, criações irrepetíveis. Aqui temos aproximado também o conceito de autoria infantil, mas isso é uma outra conversa. Esses têm sido nossos postulados e propósitos nos mapas vivenciais.

Primeiro, a gente parte do princípio que os mapas narrativos, como eles trabalham com essa coisa do mundo vivido do sujeito, ele parte do sujeito para a representação. No nosso caso, nós estamos partindo do mundo ofertado, que é onde a gente vai trabalhar, partímos desse "entre lugar", que é o conceito de vivência, do mundo ofertado, para ver como a criança interpreta esse mundo ofertado. Então a gente trabalha no campo da criação desse mundo dado para as crianças. Esse é o nosso ponto geodésico: a fronteira do individuo com o mundo dos indivíduos.

\section{É como a maneira da criança fazer uma leitura. Como ela vai fazer algum tipo de leitura.}

Esse é um projeto atual que está se desenvolvendo no grupo e que se vincula ao conceito de autoria infantil. Estamos fechando uma pesquisa agora sobre bebês, com o pessoal da UFMT. Esse trabalho foi feito nos berçários lá em Cuiabá em conjunto com a professora Daniela Freire. A gente está apresentando, a nova pesquisa que nós vamos conduzir é sobre o perfil de lógicas e autorias infantis. Ver como a criança de fato exerce essa autoria na leitura do mundo e que permite a criação constante disso.

\section{Trabalhar com os materiais e análises?}

A proposta é levantar esse material. Está baseado numa pesquisa que o Vigotski cita, é uma atividade feita na Alemanha, por um professor, chamado de Giese, antes da grande guerra que os assolou. Ele pede às crianças que produzam textos livres. E aí ele vai levantar nesses textos livres, indícios de autoria. Ele vai tentar ver o que seriam produções autorais ali presentes.

A Professora Marisol Barenco de Melo quer replicar essa pesquisa com crianças no Rio de Janeiro. Só que ela vai priorizar o texto e nós a cartografia. Vamos tentar ver os índices de autoria nas produções cartográficas das crianças. Então acredito que a gente vá começar a pesquisa, em duas frentes: em Juiz de Fora comigo e Niterói com as Professoras Marissol Barenco, a Zoia Prestes e Tânia de Vasconcellos.

A gente vai tentar levantar isso, autoria das crianças, por meio dos dados cartográficos, porque é um conceito que para nós, dentro dessa ideia da infância, fundamental para a gente começar a trazer para o debate da Educação Infantil também. Para poder pensar os currículos de Educação Infantil.

Olh@res, Guarulhos, v. 2, n. 2, p. 301-334. Dezembro, 2014. 
Como você tem pensado essa questão da Geografia da Infância e o currículo da Educação Infantil?

Uma das questões que a gente tem discutido, considerando que é um grupo grande e temos investigadores de várias áreas, Uma das razões de aproximação foram as preocupações em torno da espacialidade. E foi para mim interessante, porque tanto a Professora Marissol Barenco, quanto a própria Tânia Vasconcello, já tinham uma experiência muito longa e grande com Educação Infantil, com creches inclusive.

Aparecem sempre duas grandes demandas. A primeira demanda é sempre ligada à organização espacial das escolas de Educação Infantil. Como se organiza o espaço de uma creche? Como se organiza o espaço da Educação Infantil? São perguntas freqüentes.

Esse projeto que estou falando para vocês de Cuiabá é um exemplo disso, financiado pela CAPES, foi desenvolvido em conjunto com a professora Daniela Freire, lá da UFMT. A proposta inicial era pensar a organização espacial dos berçários de Cuiabá. Foi um trabalho muito interessante e significativo.

Mas, infelizmente, percebemos que quando esse debate espacial chegou na educação, sobretudo na educação de criança, ainda prevalecia uma visão muito determinista. Aquela coisa bem assim, organiza o espaço desse jeito, que está garantido o desenvolvimento da criança. Para nós foi muito expressivo discutir isso.

A outra demanda refere-se, especificamente, a Geografia mesmo. Perguntas que presenciamos: como trabalhar mapas, com criança, como trabalhar geografia com as crianças? Coisas bem pontuais aparecem? São temas que aparecem muito também, nos nossos cursos de formação.

E aí, no grupo, o que a gente vem discutindo? A gente tem feito uma reflexão, de pensar o currículo da Educação Infantil, nessa lógica mais ampla, ancorado nos conceitos contemporâneos de currículo. Do currículo enquanto totalidade, não só listagem.

Mas a gente tem dado muito foco também nessa questão da organização espacial, nesses últimos anos. Porque isso como foi uma coisa que apareceu e vem aparecendo com muita força e essa lógica do determinismo, acaba sendo muito presente, a gente tem feito debate muito grande com elas, até porque a gente vem exatamente dessa questão do processo de vivência da criança. Então, esse tem sido um ponto nevrálgico.

E o outro ponto é também realmente discutir a questão da Geografia mesmo. De que seria pensar uma Geografia para crianças tão pequenas? Uma Geografia com as Crianças pequenas. Por isso o projeto das lógicas e autorias infantis nos é importante. E aí, os aportes que a gente vem trabalhando são os aportes da teoria de História Cultural e os estudos também sobre esses grupos da infância, da Sociologia que a gente acabou de comentar.

Os estudos da infância trouxeram alguns princípios gerais em relação à infância que promoveram novas formas de olhar as crianças, e entre esses princípios, um fundamental é a ideia do protagonismo infantil, essa ideia da criança enquanto sujeito protagonista. $\mathrm{O}$ de participação. A gente tem levado esse

Olh@res, Guarulhos, v. 2, n. 2, p. 301-334. Dezembro, 2014. 
debate também para dentro dos espaços de formação e da reflexão curricular. E aí então, por exemplo, quando a gente discute a questão espacial com elas, primeiro a gente enxerga como a criança entra na lógica da produção do espaço daquela creche, entendeu? Então a questão é que a gente sempre tenta trabalhar muito: se estamos dizendo que as crianças são protagonistas e são produtoras de cultura, são sujeitos que produzem também a História e a Geografia Humana, a gente, tem pensado em como elas podem nos ajudar a pensar o próprio cotidiano e as rotinas das creches e da Educação Infantil! Esses são os nossos propósitos.

Estamos trabalhando a partir dos trabalhos por projetos. Mas não são aqueles movimentos clássicos dos projetos. É uma questão que se aproxima muito do debate do Paulo Freire, Freinet e outros. Estamos trazendo autores que tiveram essas experiências em suas trajetórias. Então o próprio Paulo Freire, o próprio Freinet, é uma coisa que dá para a gente fazer diálogo.

E como temos feito? A partir de eventos vividos dentro da creche, quer na ótica das crianças, quer na ótica dos adultos, ou seja, no encontro, na unidade, na vivência, são tirados temas, que viram situações a serem trabalhadas com as crianças. E, a partir desses temas, é que a gente vai dialogando com os conteúdos curriculares, quando eles são necessários de serem chamados.

E aí, a gente lança mão de alguns princípios da pedagogia de projetos. A gente faz algumas questões e levantamos o que chamamos de índice. Um exemplo: um dia desses, entre as crianças surgiu uma conversa sobre plantas carnívoras, dentro da creche. Muitas perguntas emergiram. Por votação o coletivo de crianças e adultos decidiriu conhecer mais sobre esse assunto. Partiu-se para levantar o índice. $\mathrm{O}$ que seria o índice? A gente pergunta o que a gente já sabe sobre aquilo que a gente quer estudar. As crianças não escrevem, então a professora vai registrando. E aí depois, a gente vai para a pergunta seguinte: o que nós queremos saber? E aí vem, então, as questões que serão a base da pesquisa. Porque a gente está trabalhando dentro dessa lógica do protagonismo infantil e das crianças coprodutoras de conhecimento também.

Levantam essas questões: o que a gente já sabe sobre o tema? E aí depois a gente pergunta o que a gente gostaria de saber? Essas questões respeitam as lógicas infantis. Tudo é considerado pertinente, não tem coisa que não é importante. E aí, a gente combina com o grupo da sala, com o coletivo da sala, como a gente vai tentar responder àquelas perguntas. É nesse momento que traçamos ações e que os conteúdos são acessados para ajudar a responder àquelas inquietações. Então, por exemplo, se tem questões que a Geografia tem que entrar, que possa contribuir, vamos fazendo um diálogo. Então, é dessa forma, existem alguns conceitos, a gente faz a separação lá na creche. Alguns conceitos que a gente considera que são importantes passar toda vez que for possível com os meninos, habilidades a serem desenvolvidas e princípios de atitudes do mundo, sabe assim? A gente considera que são fundamentais.

O projeto, o currículo vai sendo organizado dessa forma, não tem tempo para terminar, a gente termina o projeto, quando o grupo chega na situação de que aquele tema se esgotou, entendeu? Entramos com os princípios da Geografia e das outras áreas como 
pontos de diálogo, com a rotina e o cotidiano que vem sendo trabalhado na própria creche.

\section{São encaminhamentos que ajudam os}

\section{professores a fundamentarem suas}

\section{práticas?}

A gente trabalhou, por exemplo com as eras geológicas nas conversas com as crianças. Elas começaram a discutir o fim dos dinossauros, a extinção, nós acessamos as teorias, foram lidas para elas, fizemos uma votação em qual eles queriam acreditar. Porque a gente está partindo do princípio aqui (àquele histórico cultural, que o Vigotski assinala) que é essa coisa de você tirar a criança para ela ir além de si própria, essa é a grande lógica do processo, que vai transformar $o$ desenvolvimento do ponto qualitativo.

Então, a nossa lógica é essa. A gente não está preocupado que a criança aprenda os conteúdos de Geologia, não é isso. Mas que elas possam efetivamente, a partir do acesso aos conceitos, ressignificar os conceitos, indo sempre além do que elas já trazem. E aí, essa internalização, o enraizamento desses processos ficam por contar delas. A gente oferece a intencionalidade pedagógica do processo de ir além.

É ampliar o ser e estar no mundo das crianças. Por exemplo, a gente vê como as crianças, depois desse projeto, começaram a usar os termos que eram desconhecidos para elas, paleontólogos, fósseis eram palavras que não faziam parte do cotidiano delas. Elas criam assim, transformando-se. Há uma situação, que vale ressaltar o $\quad$ G2 resolveu fazer uma expedição no entorno da creche para coletar fósseis. Eles coletaram gravetos e tudo. Aí, vira um garoto e fala assim: "-Pois, olha só, nós coletamos muitos gravetos fósseis, não é?" São palavras criadas, são reelaborações criativas.

Então você vê o poder de protagonismo infantil, o que a gente tem nomeado como faz de conta das crianças é na verdade um grande poder de abstração delas no e para o mundo. Por isso que a gente vem questionando as teorias clássicas da própria Geografia que ainda é muito fundamentada na cognição. Dos princípios e conceitos. E aí, é nesse movimento que a gente vai avançando com eles nos currículos. Nesse projeto mesmo, por exemplo, chegou um momento em que as crianças resolveram fazer um teatro para falar sobre a extinção dos dinossauros. Sempre buscamos ampliar a maior parte das linguagens possíveis. E aí teve um garoto que virou e falou assim: "-Mas olha, eu não concordo com essa teoria. Eu acho que..." Aí a gente: "-Não, mas tudo tem evidência." Aí ele: “-Não, mas eu acho o seguinte, deve haver evidências de que esses dinossauros fugiram para algum lugar e estão ai até hoje." [risos]. Então nós do G3 estamos criando uma outra teoria de que houve meteoro sim, um meteorito sim, que caiu na Terra, tal e tal. Mas os dinossauros conseguiram fugir, mas nós não sabemos onde eles estão.

São exercícios de levantar hipótese, de a gente se posicionar no mundo, a partir, inclusive de tencionar o próprio conhecimento pré-existente, que é uma coisa que a gente vem trabalhando muito com eles. É a ideia de que esses saberes não são absolutos, eles são saberes que podem ser reconfigurados, reconstituídos e tal. Então é um pouco essa a ideia de um currículo para

Olh@res, Guarulhos, v. 2, n. 2, p. 301-334. Dezembro, 2014. 
educação infantil que garanta a seriedade da participação e do protagonismo das crianças e dos adultos. Pois, esse é currículo que a gente fez, diálogo com saberes historicamente construídos, com os saberes acadêmicos, mas também saberes de quaisquer outros sujeitos, que passam por nós ali na creche.

Agora, na Geografia, a gente vem trabalhando assim, com aqueles conceitos clássicos de grupo, de espaço, entre as subdivisões deles e com essa habilidade. A gente sempre, todos usam assim, ao invés de trazer mapa, de trazer a cartografia, de trabalhar com orientação, os outros conceitos clássicos, sempre que possível, eles são apontados dentro dos trabalhos de projetos das dúvidas e questões das crianças. Como também os conceitos clássicos da história, são trabalhados também. Trabalhamos com essa ideia de levá-los a ir além de si mesmo.

Temos pensado assim, usa-se, é claro, essa referência, mas nós também vamos pensando um pouco essa lógica para todo o trabalho que estamos fazendo, inclusive com os berçários. Porque a gente tem projetos desenvolvidos aqui em Juiz de Fora, com crianças de zero a dois anos também. Temos tentado ampliar para outras áreas também essa situação. Mas a preocupação com o conhecimento geográfico é presente. Vigotski dizia que são os processos de instrução que são capazes de gerar transformações. Criamos situações sociais de desenvolvimento, temos nossas intencionalidades pedagógicas, mas não controlamos a iminência da criação e produção humana, sobretudo das crianças. A propósito, descobri mais tarde que os dinossauros fugiram para
Dotcha, mas infelizmente não conheço esse lugar, só as crianças.

\section{Os conhecimentos passam a ser um veículo da discussão e não o fim.}

Isso!

\section{Que é um grande debate mesmo, sobre o currículo da Educação Infantil.}

Zoia: “ - Para Vigotski o conhecimento é um instrumento.

Jader: - Exatamente. É assim que a gente tem pensado. É o currículo geral, que seria assim, fundamentado, não é? Dos teóricos que estudaram a infância tanto do desenvolvimento, como Vigotski, o próprio Walloon. Outros teóricos, que ajudam nesse debate, foram o Freinet, o Paulo Freire. Mas também dos teóricos da área da infância, da Sociologia e também da Geografia. A própria, e aí entrando conceitos, isso é o fundamento do currículo básico. E os conhecimentos entrando em diálogos a partir dessa lógica de protagonismo infantil, da autoria infantil, da autonomia, do ser e estar no mundo. E aí, nesse sentido assim, entendendo o currículo como um todo.

Por exemplo, quando a gente começou a trabalhar lá na creche, uma das coisas que a gente pensou foi na organização espacial vinculada à questão das lógicas espaciais infantis. Isso ajudou muito a gente a pensar o espaço da creche. Então, por exemplo, lá na creche há uma parte em que você tem flores no chão, o caminho das flores. Que na verdade dá o acesso à criança desde a entrada às salas de atividades e aos pátios. Ali, as crianças sabem que

Olh@res, Guarulhos, v. 2, n. 2, p. 301-334. Dezembro, 2014. 
onde tem flores, elas podem ficar sem a presença do adulto. Trata-se de um sistema de orientação construído por nós e combinado com as crianças. Onde tem outra marcação, elas podem estar, tem que estar sempre com a presença de um adulto. Tem lugares, que são espaços mais vedados. Outro exemplo: os cabides. Logo que as crianças chegam no início do ano, elas mesmo escolhem qual cabide vão colocar as mochilas e elas então desenham um símbolo para poder marcar. No nosso caso, a gente já vai fazer a utilização da legenda, da cartografia. É uma marcação da localização espacial. Então é assim que a gente vai dialogando, sabe? A gente vai pegando os nossos currículos, as nossas bases da Geografia e vai trazendo esse materiais para o cotidiano vivido.

Quanto a produção e organização do espaço, já é combinado com elas que elas vão produzir o espaço conjuntamente os demais adultos da instituição, para acolhê-las e para acolher também as demais pessoais que ali vivem. Porque, a final de contas, o espaço é do coletivo. Partimos do que Bakhtin nos ensinou: os espaços não falam só sobre as pessoas, os espaços falam com as pessoas, Bakhtin fala em relação aos textos literários, nós é que estamos transcrevendo para a dimensão espacial. Então é essa ideia: aquela organização está dando um recado, ela está dizendo alguma coisa para as crianças e para todos que ali chegam. É registro e memória do grupo. Então é fundamental elas estarem ali também nessa produção.

Outro dia eu estava comentando que o entorno da creche tem uma boa área verde. Percebemos pelas nossas observações que as crianças quando chegam percorrem um caminho de cimento que tem umas folhagens e arbustos. Vimos que quando elas chegam vão sempre passando a mão ali. Um dia uma criança chegou correndo, passou a mão, e falou: "-Olha pai, olha como a minha mão está cheia de verde." Discutimos essa questão da criança passar a mão nas folhagens: "-Então vamos... Se isso é uma ação que elas fazem..." Aí a própria Tânia, chamou a atenção: "-Vamos tentar logo depois que acabar algumas obras, plantar ali uma série de plantas que tem cheiros também, para que na hora que elas passarem, elas sentirem não só o verde, mas os odores." É dessa maneira que a gente vai tentando observar essas vivências, essas lógicas espaciais infantis e isso vai entrando em um diálogo com a própria Geografia. A Geografia pode e deve contribuir com esse trabalho. E dentro disso, a questão mesmo dos projetos maiores. Teve um agora recentemente, sobre medos. Eles fizeram um mapeamento da creche super interessante, mostrando onde provavelmente tinham fantasmas na creche. Porque eles estavam querendo pegar esses fantasmas. Então assim, a gente deixa as lógicas infantis irem e junto com elas, a gente vai caminhando, nos deslocando constantemente de nossos locais habitados.

\section{Construir referências locacionais com as crianças?}

Sim, é. Esse mapa, até pedi para o professor guardar, eu ia até usar o desenho, porque ficou muito interessante elas mapeando os lugares onde elas acham que os fantasmas estavam. A

Olh@res, Guarulhos, v. 2, n. 2, p. 301-334. Dezembro, 2014. 
gente usa muito o próprio material produzido por eles para poder reorganizar o espaço das paredes. Houve um dia pela manhã que as crianças ao chegarem na sala da turma encontraram alguns trabalhos feitos por elas, que estavam nas paredes, caídos no chão. A turma já estava nesse projeto dos fantasmas e uma criança falou: "-Olha, provavelmente foi um fantasma à noite que apareceu aqui." Aí eles foram rapidamente na sala, pegaram o lápis que a gente deixou lá, e marcaram, fizeram uma legenda...eles próprios. Essa é a perspectiva. Sem saber que é um debate geográfico, um debate da História, da Matemática vão se inserindo a partir de suas investigações, explicações, escritas....usam os recursos, os saberes da ciência geográfica como forma de ampliar suas ações no mundo, de ler os eventos a partir de múltiplas possibilidades, tecendo suas próprias escolhas.

Nesse projeto, por exemplo, dos dinossauros, houve um momento que quando eles viram o tamanho dos dinossauros, eles quiseram fazer medições. Aí a gente usou o gramado da Educação Física, eles deitaram lá no chão, a professora levou o tamanho que era o dinossauro e eles foram se deitando, usando o corpo, para ver quantas crianças precisavam para poder chegar ao tamanho do dinossauro. Nesse movimento estamos em uma lógica de escala, proporção. As crianças investigam comparam discutem... A gente dá as ações fazendo isso, então a gente vai orientando nas questões pedagógicas, onde pode entrar o diálogo com os saberes mais acadêmicos.

Um dos problemas da questão do currículo da Educação Infantil é a compreensão de que ele teria que estar prescrito na lógica da cultura escolar, da escolarização. Em uma das nossas experiências observadas na Educação Infantil, a escola dizia trabalhar com a pedagogia de projeto, com um tema clássico, que era Educação Ambiental. Ao desenvolverem as ações pedagógicas, foram cortando e apareceu a questão da água no debate, na discussão. Nesse momento, tinha uma aluna nossa fazendo a residência pedagógica, acompanhando os trabalhos da professora. No meio do processo a aluna observa um problema que até então, aparentemente, ninguém tinha dado a devida importância, que acreditamos que merecia. Qual era o problema? A escola de Educação Infantil fica em um bairro "periférico" de Guarulhos, um bairro no qual há um rodízio de água, e durante dois ou três dias as famílias ficam sem água. Nesse contexto, a escola desenvolvia um trabalho a partir da lógica de que as crianças devem fechar a torneira, de que elas têm que economizar água. $A$ aluna anotou isso no seu caderno de campo e nós transformamos num debate formativo. Quando li essa anotação a transformei numa situação de aprendizagem e comentei: "-Aqui está o mundo: eu tenho que perguntar para a professora como ela faz para educar essa criança para fechar a torneira num bairro no qual a oferta de água não é diária”. Tendo essa situação como referência, a aluna propôs um plano de ação pedagógica no qual ela reverteu tudo. Foi na perspectiva do quê? Do protagonismo infantil: "-Vamos escutar as crianças. $O$ que elas acham sobre isso." $\mathrm{E}$ aí se criou uma situação nova, de escuta. A

Olh@res, Guarulhos, v. 2, n. 2, p. 301-334. Dezembro, 2014. 
escola se concentra, às vezes, no currículo prescrito e ignora, portanto, as crianças enquanto sujeitos. É a tal da infância invisível.

Isso é muito comum. A gente estava no PBID da Educação Infantil, quando começamos a acessar as escolas, a primeira coisa que fizemos foi conhecer o projeto pedagógico do município de Niterói, para ver qual é a proposta pedagógica para a Educação Infantil. Depois procuramos ver alguns princípios. Constatamos que muitas escolas, não querem trabalhar com Pedagogia de projetos. Por exemplo, identificamos que em muitas escolas chegava o início do ano e a programação era feita para o ano inteiro. Assim, então, são os temas clássicos mesmo, inclusive a educação ambiental, é que vai aparecendo.

\section{Folclore.}

Aparece muito, uma coisa que nos assusta muito, é a questão de datas comemorativas. São muito presentes. Aqui em Juiz de Fora nos tivemos a oportunidade de construir um currículo. Foram quase cinco anos de trabalho com os professores. Foi uma experiência bem legal. O que fizemos? Criamos um grupo de estudos. Os encontros ocorriam uma vez por mês, toda quarta-feira. Estudamos os materiais, convidamos pessoas da área da infância para conversar coletivamente e no encontro seguinte a gente tentava sistematizar o que aquilo, por exemplo, poderia entrar em uma proposta curricular, em um projeto para ser escrito em um caderno de Educação Infantil. Foi uma coisa que deu muito trabalho, mas o retorno foi estimulante.

As pessoas que entravam no grupo se inscreviam e a gente debatia. Reunia aquilo e tentava fazer um texto coletivo. Foram mais de cinco anos, porque ficou pronto o ano passado e começou na outra administração. E assim, foi bem interessante, porque ele ia e voltava muito para as escolas. E aí as coisas são escritas muito coletivamente mesmo. Assim, quando dava algum nó, que a gente às vezes ficava em dúvida, então: "-Vamos chamar uma outra pessoa para vir." Muitos colegas contribuíram nas discussões, por exemplo as Professoras Marissol Barenco, Ângela Mayer Borba e Tânia Vasconcellos . As pessoas vinham e falavam sobre as questões demandadas. E aí, o grupo, então, decidia como aquilo poderia ser incorporado no o currículo.

E o que foi interessante, é que muitas das questões que iam ser debatidas, como eram tratadas com alguns professores, professoras já da Educação Infantil, elas tentavam também trabalhar no cotidiano. Então, acabava que elas traziam situações que acabaram virando depois exemplos do próprio material que estava sendo organizado. A maior parte das fotos que estão no livro $A$ Prática Pedagógica na Educação Infantil diálogos no cotidiano - Proposta Curricular da rede municipal de Juiz de Fora, 2011. São situações reais constituídas a partir desse núcleo de trabalho. Foi uma coisa feita de forma coletiva mesmo.

E aí, claro, houve muitas tensões em relação às pessoas. Mas assim, foi legal, porque quando as pessoas viram a seriedade do movimento e a ideia de fazer uma coisa mais conjunta, as

Olh@res, Guarulhos, v. 2, n. 2, p. 301-334. Dezembro, 2014. 
pessoas depois se desarmaram muito e começam a trabalhar com...

\section{Foi mais difuso?}

Foi, mas no final foi ótimo. Foi um movimento, assim, que me deu muito trabalho, porque eu estava na ponta dele, na coordenação, tinham muita gente trabalhando junto. Mas no final das contas, acaba sempre: organiza texto, faz isso, faz aquilo. Mas eu achei que foi uma experiência bem legal. Vocês vão ver, tem contradições, inclusive, mas elas expressam o grupo, a verdade é essa, entendeu? Assim, coisas que aconteceram assim e que a gente fez questão de deixar.

\section{É até a questão do respeito. É uma rede que já tem uma história.}

Exatamente, tem potencial. As próprias professoras e professores perceberam. Quando a gente estava no meio da discussão, o trabalho de doutoramento da Zoia saiu, nós incorporamos esse documento nos estudos e debatemos a tese. Já estava bem no final alguns trechos, houve um grande debate se ficava proximal ou eminente, se Vigotski era com I ou se era com Y. Até essas coisas de pedagógico, para você ter uma ideia. Mas assim, foi ficando situações que foram decididas na coletividade ali, entendeu? Então foi uma tentativa e, a meu ver, ficou um documento bem interessante. E está constituído dentro dessa lógica que eu acabei de dizer para vocês.
É um exercício que não é muito fácil de ser conduzido.

Mas foi legal, sabe? Assim, eu acho que valeu a pena a gente fazer. E está dentro dessa lógica curricular que vocês estão perguntando. Mas então um pouco é isso, lá no grupo a gente vai fazendo esse movimento assim, das pesquisas e também dessa coisa de discutir a questão do cotidiano mesmo da Educação Infantil. E a nossa contribuição para esse cotidiano. Então, a gente tem essa imersão na creche, mas está muito além dela. Temos trabalhado em outros lugares do município. Por exemplo, atualmente estamos trabalhando com a formação do pessoal de Itaboraí. Esse município do Rio de Janeiro está com uma particularidade, que é a presença daquele complexo da Petrobras. Isso dinamizou aquele lugar. Virou numa área de migração, um monte de gente do mundo inteiro, inclusive, as escolas públicas recebendo esses rebatimentos com crianças de diferentes origens e a gente está lá tentando constituir um trabalho da Educação Infantil junto delas-

No que tange as políticas públicas hoje, principalmente na área de Educação Infantil, elas nos últimos anos vêm crescendo. Vocês estão fazendo alguns trabalhos que as políticas públicas, talvez pelo grau de maturação, não tenham chegado ainda nesse ponto. Como funciona esse diálogo no grupo?

É o que a gente tem debatido muito. Como interferir nos rumos dessas políticas pública, essa é uma grande

Olh@res, Guarulhos, v. 2, n. 2, p. 301-334. Dezembro, 2014. 
questão. E como a gente faz isso? Existem movimentos coletivamente organizados, que tem sido um dos nossos caminhos também. Por exemplo, eu apesar de ser da Geografia, atuo muito na ANPED, estou no Grupo de Trabalho (GT) de Educação Infantil. Porque a gente sabe que é um GT que tem força e ajudou muito a construir as políticas públicas da infância desse país.

Existem os fóruns, os movimentos, os fóruns de Educação Infantil, que a gente volta e meia participa. Por exemplo, a minha vinda para UFJF, um dos meus desejos, é reativar o fórum de Educação Infantil na cidade. Porque, por exemplo, precisamos repensar, a questão das creches que até hoje não está resolvida no município de Juíz de Fora. Há uma situação na qual as creches, apesar de estarem na esfera da Educação, elas ainda pertencem à uma fundação municipal, que criou, que abrigava essas creches. E essa fundação atua mais no plano administrativo se distanciando da educação.

\section{Tudo politicamente pedagogicamente.}

Por todo lado. E o que foi feito? Qual foi a saída que se encontrou até o momento? Naquele momento, foi trazer a questão pedagógica para a secretaria. Então hoje, é claro que esse material teve muita gente participando, mas a alocação delas ainda continua nessa área. Então, administrativamente, a na proximação das creches das questões pedagógicas é um grande debate aqui na cidade, que não está resolvido, inclusive tem sido tenso e intenso.

Jader, você pode nos contar um pouco sobre a Creche da UFF?
Bem funcional com as crianças, porque é um espaço que tenta trabalhar muito essa lógica da autonomia, da autoria. As salas não têm portas, os adultos são todos corresponsáveis por todas as crianças, não tem essa coisa de a criança é dessa professora, então, ela é a responsável. Qualquer adulto, em qualquer local é responsável por uma criança que está ali dentro. Então, por isso elas podem ter a autonomia do deslocamento, então, fica sempre um adulto pronto para cuidar de alguma coisa que for necessário.

Esses professores que você comentou que vão para a creche, tem a informação, e eles conhecem essa realidade. Mas aí eles voltam para a escola. Como vocês avaliam o impacto para a outra escola concreta?

É isso que a gente pensa que é o impacto de formação que é possível fazer, que é ótimo. Porque, na verdade, eles fazem uma formação de fato no contexto ali, porque eles vivenciam aquilo. $\mathrm{O}$ que não é fácil, porque todo ano a gente tem que reiniciar o trabalho. Mas o que a gente acredita é que a volta deles faz alguma diferença para onde eles vão.

\section{Que é uma prática formativa.}

É. E eu vejo assim, lá em Itaboraí, tem uma professora que foi da creche. E a gente vê o trabalho que ela faz, é um trabalho bem diferenciado. A gente vê que há uma formação. $\mathrm{Na}$ verdade, eles veem que o trabalho é possível. Eu acho que é bem por aí. Porque a questão do ensino tendo como

Olh@res, Guarulhos, v. 2, n. 2, p. 301-334. Dezembro, 2014. 
referência o trabalho centrado na criança adquire outra densidade.

\section{É mais uma questão de concepção?}

É também, assumir a concepção de infância que cremos faz toda a diferença. Por isso o trabalho acadêmico é fundamental. Após anos de pesquisas em nosso grupo, podemos compartilhar com vocês uns dados que ainda estão inéditos e que serão publicados pela primeira vez aqui, trata-se das lógicas espaciais, infantis, eis algumas:

- As crianças vivenciam o espaço como processo e não como palco, local de passagem ou superfície ocupada; o espaço não é concebido como métrico, como extensão, mas como intensidade; noções como "lá" e "cá"; "perto", "longe" e outras nem sempre coincidem com os recortes espaciais tradicionais dos adultos;

-Na vivência do espaço as crianças não estão construindo outros espaços dentro do espaço, elas estão produzindo uma espacialidade não existente; constituem "setting", "sítios espaciais" que envolvem seus fazeres nas rotinas cotidianas, essa situação foi muito evidenciada nas atividades do brincar;

- Na vivência dos elementos das paisagens, diversos sentidos se cruzam: olfato, tato, audição, paladar são acionados em sua plenitude e não em seus isolamentos, temos reconhecido essa situação por vivências intermodais; em campo foi possível recolher narrativas como: "é a sombra da árvore que deixa o pé ver as pedras" (nota de campo, 2011);
- A vivência espacial das crianças ao mesmo tempo ocorre em "locais" no espaço, como cantos, frestas, arestas; mas também ao todo, ao seu interno e externo e em seus contínuos. As unidades espaciais vividas não são ilhas isoladas, mas continentes, onde a noção de interior e exterior se fundem; reafirmando a ideia de que dentro/fora é vivido de forma bem própria;

- Existe o reconhecimento de espaços tidos como proibidos, muitas vezes acessados a partir de seus encontros com os pares (o que nos tem feito perguntar: seria uma subversão do espaço dado, do instituído? As crianças reconhecem essa condição de subversão? Essas são questões que ainda precisam ser aprofundadas);

-Existe uma criação/invenção constante da forma original dos objetos, dos artefatos de infância e das maneiras como são utilizados, como os brinquedos presentes nos parques, nas praças e em outros locais, que geralmente fogem ao definindo em seu padrão inicial, em sua função primária;

- A criação de palavras, nomes próprios para designar os arranjos espaciais é algo constante; mesmo nascendo ou chegando a um espaço previamente elaborado, dado, o momento inaugural, autoral está sempre presente.

Tudo isso será lançado num livro que estamos organizando e que deverá sair em 2014 ou 2015, o título já está fechado, provavelmente irá ser chamado de Espaço desacostumado, a Geografia das Crianças e a Geografia na

Olh@res, Guarulhos, v. 2, n. 2, p. 301-334. Dezembro, 2014. 
Educação Infantil. O conceito de espaço desacostumado foi cunhado por nós nesses anos de trabalho e pesquisa. É um conceito novo que estamos assumindo e propondo no envolvimento com as crianças pequenas. Aprendi em boa parte de minha graduação acadêmica que as crianças vivenciam suas espacialidades de "uma realidade mais próxima para a mais distante", que são "espaços simetricamente arranjados que vão gradativamente ampliando", porém, conviver com as crianças me desacostumou a isso, um dia lendo Manuel de Barros, encontrei a seguinte poesia...

Nosso Profe. de latim, Mestre Aristeu, era magro e do Piauí. Falou que estava cansado de genitivos dativos, ablativos e de outras desinências. Gostaria agora de escrever um livro. Usaria um idioma de larvas incendiadas! Mestre Aristeu continuou: quisera uma linguagem que obedecesse a desordem das falas infantis do que das ordens gramaticais. Desfazer o normal há de ser uma norma. Pois eu quisera modificar nosso idioma com as minhas particularidades. Eu queria só descobrir e não descrever. O imprevisto fosse mais atrente do que o dejá visto. $O$ desespero fosse mais atraente do que a esperança. Epa! O profe. Desalterou de novo - outro colega nosso denunciou. Porque o desespero é sempre o que não se espera. Verbi gratia: um tropicão na pedra ou uma sintaxe insólita. O que eu não gosto é de uma palavra de tanque. Porque as palavras do tanque são estagnadas, estanques, acostumadas. E podem até pegar mofo. Quisera um idioma de larvas incendiadas. Palavras que fossem de fontes e não de tanques. $E$ um pouco exaltado o nosso profe. Disse: Falo de poesia, meus queridos alunos.

Olh@res, Guarulhos, v. 2, n. 2, p. 301-334. Dezembro, 2014.
Poesia é o mel das palavras! Eu sou um enxame! Epa!... Nisso entra o diretor do Colégio que assistira a aula de fora. Falou: Seo Enxame espere-me no meu gabinete. $O$ senhor está ensinando bobagens aos nossos alunos. $O$ nosso mestre foi saindo da sala, meio rindo a chorar.

Manuel de Barros

Foi ai que forjei em mim mesmo a noção de espaço desacostumado... aprendi que crianças não gostam de se acostumar ao mundo e nem aos espaços geograficamente construídos. Todos os adultos deveriam aprender isso: Esse espaço desacostumado é que é a Geografia na Educação Infantil.

\section{Muito obrigado! \\ FIM DA ENTREVISTA}

